\title{
Pathophysiology of perinatal asphyxia: can we predict and improve individual outcomes?
}

\author{
Paola Morales • Diego Bustamante • Pablo Espina-Marchant • \\ Tanya Neira-Peña • Manuel A. Gutiérrez-Hernández • \\ Camilo Allende-Castro • Edgardo Rojas-Mancilla
}

Received: 29 April 2011 / Accepted: 20 May 2011 / Published online: 26 July 2011

(C) European Association for Predictive, Preventive and Personalised Medicine 2011

\begin{abstract}
Perinatal asphyxia occurs still with great incidence whenever delivery is prolonged, despite improvements in perinatal care. After asphyxia, infants can suffer from short- to long-term neurological sequelae, their severity depend upon the extent of the insult, the metabolic imbalance during the re-oxygenation period and the developmental state of the affected regions. Significant progresses in understanding of perinatal asphyxia pathophysiology have achieved. However, predictive diagnostics and personalised therapeutic interventions are still under initial development. Now the emphasis is on early noninvasive diagnosis approach, as well as, in identifying new therapeutic targets to improve individual outcomes. In this review we discuss (i) specific biomarkers for early prediction of perinatal asphyxia outcome; (ii) short and long term sequelae; (iii) neurocircuitries involved; (iv) molecular path-
\end{abstract}

P. Morales $(\bowtie) \cdot$ D. Bustamante $\cdot$ P. Espina-Marchant •

T. Neira-Peña $\cdot$ M. A. Gutiérrez-Hernández $•$ C. Allende-Castro $•$

E. Rojas-Mancilla

Programme of Molecular \& Clinical Pharmacology, ICBM,

Medical Faculty, University of Chile,

PO Box 70.000, Santiago 7, Chile

e-mail: pmorales@med.uchile.cl

D. Bustamante

e-mail: dbustama@med.uchile.cl

P. Espina-Marchant

e-mail: pa_espina@med.uchile.cl

T. Neira-Peña

e-mail: tanyaneira@gmail.com

M. A. Gutiérrez-Hernández

e-mail: manugut@med.uchile.cl

C. Allende-Castro

e-mail: allende.camilo@gmail.com

E. Rojas-Mancilla

e-mail: esrojas@med.uchile.cl ways; (v) neuroinflammation systems; (vi) endogenous brain rescue systems, including activation of sentinel proteins and neurogenesis; and (vii) therapeutic targets for preventing or mitigating the effects produced by asphyxia.

Keywords Neonatal $\cdot$ Hypoxia-ischemia $\cdot$ Predictive diagnostic $\cdot$ Sequelae $\cdot$ Personalised treatments

\begin{tabular}{|c|c|}
\hline \multicolumn{2}{|c|}{ Abbreviations } \\
\hline AA & Amino acids \\
\hline AAP & American academy of paediatrics \\
\hline $\mathrm{ACOG}$ & $\begin{array}{l}\text { American college of obstetrics and } \\
\text { gynaecology }\end{array}$ \\
\hline ADP-ribose & Adenine diphosphate-ribose \\
\hline ADHD & Attention deficit hyperactivity disorder \\
\hline AIF & Apoptosis-inducing factor \\
\hline AMPA & $\begin{array}{l}\text { Alpha-amino acid-3-hydroxy-5-methyl-4- } \\
\text { isoxazolepropionic acid }\end{array}$ \\
\hline Apo & Apomorphine \\
\hline ATP & Adenosine triphosphate \\
\hline BAD & Bcl-2-associated death promoter \\
\hline BAX & Bcl-2-associated $\mathrm{X}$ protein \\
\hline BCL-2 & B-cell lymphoma 2 \\
\hline BDNF & Brain-derived neurotrophic factor \\
\hline bFGF & Basic fibroblast growth factor \\
\hline BrdU & 5-bromo-2'-deoxyuridine \\
\hline CA & Cornus ammonis \\
\hline CAMKII & $\mathrm{Ca}^{2+} /$ calmodulin-dependent protein kinase \\
\hline $\mathrm{Cdk}$ & Cyclin-dependent kinases \\
\hline CNS & Central nervous system \\
\hline CNTF & Ciliary neurotrophic factor \\
\hline $\mathrm{CSF}$ & Cerebral spinal fluid \\
\hline DA & Dopamine \\
\hline DAMPs & Damage-associated molecular patterns \\
\hline DAPI & 4',6-diamidino-2-phenylindole \\
\hline
\end{tabular}




\begin{tabular}{|c|c|}
\hline DG & Dentate gyrus \\
\hline DNA & Deoxyribonucleic acid \\
\hline EAAT & Excitatory amino acid transporter \\
\hline EGF & Epidermal growth factor \\
\hline ERCC2 & $\begin{array}{l}\text { Excision repair cross-complementing } \\
\text { rodent repair group } 2\end{array}$ \\
\hline RK & Extracellular signal-regulated kinases \\
\hline GFR & Fibroblast growth factor receptor \\
\hline FLRT3 & Leucine-rich repeat transmembrane protein \\
\hline GDNF & Glial cell-derived neurotrophic factor \\
\hline FAP & Glial fibrillary acidic protein \\
\hline $\operatorname{luR}$ & Glutamate receptor \\
\hline $\mathrm{HI}$ & Hypoxia-ischaemia \\
\hline HIE & Hypoxic-ischaemic encephalopathy \\
\hline $\mathrm{SC}$ & Haematopoietic stem cells \\
\hline $\mathrm{UCB}$ & $\begin{array}{l}\text { Human umbilical cord blood } \\
\text { mononuclear cells }\end{array}$ \\
\hline IGF-1 & Insulin-like growth factor-1 \\
\hline IL & Interleukin \\
\hline INF- $\gamma$ & Interferon gamma \\
\hline iNOS & Inducible nitric oxide synthase \\
\hline IQ & Intelligence quotient \\
\hline KA & Kainic acid \\
\hline MAP-2 & Microtubule associated protein-2 \\
\hline MAPK & Mitogen-activated protein kinase \\
\hline MMP & Matrix metalloproteinases \\
\hline IRI & Magnetic resonance imaging \\
\hline RNA & Messenger ribonucleic acid \\
\hline ISC & Mesenchymal stem cells \\
\hline NAD & $\begin{array}{l}\text { Nicotinamide adenine dinucleotide } \\
\text { oxided form }\end{array}$ \\
\hline NADH & $\begin{array}{l}\text { Nicotinamide adenine dinucleotide } \\
\text { reduced form }\end{array}$ \\
\hline$N F-k B$ & $\begin{array}{l}\text { Nuclear factor kappa-light-chain- } \\
\text { enhancer of activated B cells }\end{array}$ \\
\hline NGF & Nerve growth factor \\
\hline NMDA & $\mathrm{N}$-methyl-D-aspartic acid \\
\hline nNOS & Neuronal nitric oxide synthase \\
\hline NSC & Neuronal stem cells \\
\hline PA & Perinatal asphyxia \\
\hline pADPr & Poly ADP-ribose polymers \\
\hline PARP-1 & Poly ADP-ribose polymerase subtype 1 \\
\hline PKA & Protein kinase A \\
\hline $\mathrm{PKC}$ & Protein kinase $\mathrm{C}$ \\
\hline ROS & Reactive oxidative species \\
\hline SNAP-25 & Synaptosomal-associated protein 25 \\
\hline $\mathrm{SNc}$ & Substantia nigra pars compacta \\
\hline SOD & Superoxide dismutase \\
\hline SVZ & Subventricular zone \\
\hline TCA & Tricarboxylic acid cycle \\
\hline $\mathrm{TH}$ & Tyrosine hydroxylase \\
\hline$\pi S$ & Toll-like receptors \\
\hline $\mathrm{F}-\alpha$ & Tumour necrosis factor-alpha \\
\hline
\end{tabular}

$\begin{array}{ll}\text { VTA } & \text { Ventral tegmental area } \\ \text { XRCC1 } & \text { X-ray cross complementing factor } 1\end{array}$

\section{Introduction}

Perinatal asphyxia (PA) or neonatal hypoxia- ischemia (HI) is a temporary interruption of oxygen availability that implies a risky metabolic challenge, even when the insult does not lead to a fatal outcome [1]. Different clinical parameters have been used to both diagnose and predict the prognosis for PA, including non reassuring foetal heart rate patterns, prolonged labour, meconium-stained fluid, low 1minute Apgar score, and mild to moderate acidemia, defined as arterial blood $\mathrm{pH}$ less than 7 or base excess greater than $12 \mathrm{mmol} / \mathrm{L}$ [2].

The guidelines of the American Academy of Paediatrics (AAP) and the American College of Obstetrics and Gynaecology (ACOG) consider all of the following criteria in diagnosing asphyxia: (i) profound metabolic or mixed acidemia $(\mathrm{pH}<7.00)$ in umbilical artery blood sample, if obtained, (ii) persistence of an Apgar score of 0-3 for longer than $5 \mathrm{~min}$, (iii) neonatal neurologic sequelae (e.g., seizures, coma, hypotonia), and (iv) multiple organ involvement (e.g., kidney, lungs, liver, heart, intestines) [3]. Clinically, this type of brain injury is called HypoxicIschemic Encephalopathy (HIE). The staging system proposed by Sarnat and Sarnat in 1976 is often useful in classifying the degree of encephalopathy. Mild (stage I), moderate (stage II), or severe (stage III) HIE is commonly diagnosed using physical examination, which evaluates the level of consciousness, neuromuscular control, tendon and complex reflexes, pupils, heart rate, bronchial and salivary secretions, gastrointestinal motility, presence or absence of myoclonus or seizures, electroencephalography findings, and autonomic function [4]. However, these parameters have no predictive value for long-term neurologic injury after mild to moderate asphyxia [5].

$\mathrm{PA}$ is a major paediatric issue with few successful therapies to prevent neuronal damage. PA still occurs frequently when delivery is prolonged, despite improvements in perinatal care [6-9]. The international incidence has been reported as 2-6/1,000 term births [10, 11], reaching higher rates in developing countries [12-14].

\section{Prognosis and sequelae of perinatal asphyxia}

Studies of neurodevelopmental outcome after HIE often give limited information about the children, pooling a wide range of outcome severities. The emphasis in neonatology and paediatrics is on non-invasive diagnosis approaches for 
predictive diagnostics. Several methods for predicting outcomes in infants with HIE are used in the clinical setting including: neonatal clinical examination and clinical course, monitoring general movements [15, 16], early electrophysiology testing, cranial ultrasound imaging, Doppler blood flow velocity measurements, magnetic resonance imaging (MRI) and MR microscopy. The neonatal brain MRI provides detailed information about lesion patterns in HIE allowing for earlier and more accurate prediction of long-term outcome [17, 18]. Very recently, a potential serum biomarker for predicting individual predispositions to pathologies or progression of complications induced by asphyxia has been described. As HIE induces changes in blood-barrier permeability [19], a potential correlation between blood and brain can be established. Thus, the presence of specific level of lactate dehydrogenase [20] or free radicals in blood predicts HIE in newborn infant during the first $12 \mathrm{~h}$ after birth. This result is of clinical interest offering a potential inexpensive and safe prognostic marker for newborn infants with PA. Longterm follow-up studies are required to correlate the information obtained from early biomarkers predictor with clinical-pathophysiologic outcome.

The time course and the severity of the neurological deficits observed following HI depends upon the extent of the insult, the time lapse before normal breathing is restored and the CNS maturity of the foetus. Severe asphyxia has been linked to cerebral palsy, mental retardation, and epilepsy [7, 21-23], while mild-moderate asphyxia has been associated with cognitive and behavioural alterations, such as hyperactivity, autism [22], attention deficits in children and adolescents [24, 25], low intelligence quotient score [26], schizophrenia [27-29] and development of psychotic disorders in adulthood [30]. In a prospective cohort study of genetic and perinatal influences on the aetiology of schizophrenia [26,31], it was reported that individuals with hypoxia-related obstetric complications were more than five times more likely to develop schizophrenia than individuals with no hypoxia-related obstetric complications. Moreover, a downregulation of brain-derived neurotrophic factor (BDNF) has been detected in cord samples of patients exposed to PA who develop schizophrenia as adults [27]. This finding suggests that the decrease in neurotrophic factors induced by HI may lead to dendritic atrophy and disruption of synaptogenesis, effects that are present in individuals destined to develop schizophrenia as adults [27]. Moreover, in a 19-year longitudinal study, it was found that neonatal HI complications were associated with a doubling of the risk for developing a psychotic disorder [32].

Because the majority of studies have focused on detecting major developmental abnormalities at a very young age, we still know little about the less severe difficulties that children may experience later, since different levels of morbidity have been found after mild or moderate PA [33]. To understand the long-term effects of PA on development, it is necessary to follow participants through school age. Specific cognitive functions continue to develop throughout childhood, and subtle functional deficits usually become apparent when a child faces increasing demands to develop complex abilities in school. Different studies have shown that children 2 to 6 years old with mild PA have general intellectual skills comparable to control groups, and those with moderate PA obtain consistently worse results than control groups but without reaching statistically significant, differences [34-36]. When children with moderate PA are tested at 7 to 9 years, they show problems in reading, spelling and math [22, 37, 38]. Given the good prognosis of children with mild PA, the heterogeneity of moderate PA, and the devastating effects of severe PA, some authors have proposed a dose-response effect $[9,37]$.

Neurocircuitries of the hippocampus, as well as the basal ganglia [10, 24, 39-43], are particularly vulnerable to $\mathrm{HI}$ in the neonate $[18,44-50]$. Hippocampus have been associated with specific cognitive functions such as memory and attention and together with striatum, play a role in the pathogenesis of attention deficit hyperactivity disorder, autism and schizophrenia [10,51, 52]. The striatum has also been associated with cerebral palsy, a group of disorders of movement and posture development. Motor abnormalities are often accompanied by disturbances of sensation, perception, cognition, behaviour and/or by a seizure disorder [16]. Term infants exposed to severe HI show focal brain lesions in the peri-Rolandic cortex, ventrolateral thalamus, hippocampus, and posterior putamen on MRI [17, 18, 53, 54], as well as abnormalities in generalized movement patterns at 1 and 3 months of age [16]. This group also shows increased susceptibility for developing cerebral palsy, including athetosis and dystonia, with impaired motor speech and impaired use of the hands compared to the legs [54]. A recent MRI study of a cohort of 175 term infants with PA, with scans obtained at 6 weeks and at 2 years postnatally, provides compatible results [17]. The early MRIs showed marked structural damage to the deep grey matter, hippocampus, or frontal white matter, producing a long-term impact on intellectual function in the children. In particular, memory and attention/executive functions were impaired in children that experienced severe PA. Language problems were also common [17]. These MRI findings provide evidence of the close relationship between the localisation of the lesion, the severity of the HI injury, and the resulting functional impairment. A similar system-selective pattern of network degeneration in the hippocampus has been seen with diffusion tensor MRI in mice with hypoxic-ischaemic injury $[55,56]$. In agreement, 
hippocampal cell death was observed 1 week [57, 58], 1 month [43, 59-61] and 3 months [62, 63] after PA, principally in the CA1, CA3 and dentate gyrus (DG) regions of rats. Moreover, a decrease in synaptogenesis and dendritic branching of pyramidal cells has been found in hippocampal cultures from rats exposed to PA [RojasMancilla et al., in preparation] (see Fig. 1). These effects could be correlated with deficits in neuro-behavioural functions such as hyperactivity, deficits in working memory, non-spatial memory, anxiety, and motor coordination [40, $42,61,63,64-66]$ and also could be a key factor in the development of neuropathology, including schizophrenia [27].

\section{Energy deficit and calcium homeostasis}

Energy failure occurring in PA leads a radical shift from an aerobic to a less efficient anaerobic metabolism, resulting in a decreased rate of ATP and phosphocreatine formation [67-69], lactate accumulation [70, 71], decreased $\mathrm{pH}[67$, 72], decreased protein phosphorylation [69, 73-75]; and finally, over-production of reactive oxygen species (ROS) [76-80] that result in cell death. Deficit in ATP production leads to loss of resting membrane potential [81], disturbances in ionic homeostasis, membrane depolarisation [82], and an increase in extracellular glutamate concentration $[70,83]$ as shown in Fig. 2. This results in over-activation of the ionotropic NMDA (N-methyl-D-aspartic acid), AMPA/KA (Alpha-amino acid-3-hydroxy-5-methyl-4-isoxazolepropionic acid/Kainic acid) receptors as well as the G-protein-linked metabotropic glutamate receptors (mGluR) $[82,84,85]$, inducing a massive influx of $\mathrm{Ca}^{2+}$ into cells. The increase in cytosolic $\mathrm{Ca}^{2+}$, in turn, activates proteases, lipases, endonucleases, and nitric oxide synthases that degrade the cytoskeleton and extracellular matrix proteins, producing membrane lipid peroxidation, peroxynitrites, and other free radicals [44, 57, 86, 87]. These events [88-91] elicit a cascade of downstream intracellular processes that finally lead to excitotoxic neuronal damage [92-94] and cell death (see Fig. 2).

In response to the energy deficit, blood flow is redistributed to the heart, brain and adrenal glands in order to ensure oxygen supply to these vital organs. This redistribution occurs at the expense of reduced perfusion of kidneys, gastrointestinal tract, muscles, skeleton and skin $[28,69,95-97]$. In the brain there is also a redistribution of blood flow, favouring the brain stem at the expense of the cortex [98], showing a re-compartmentalisation of structures to privilege survival [69]. Re-oxygenation can lead to improper homeostasis, partial recovery, and sustained overexpression of alternative metabolic pathways, prolonging the energy deficit and/or generating oxidative stress.
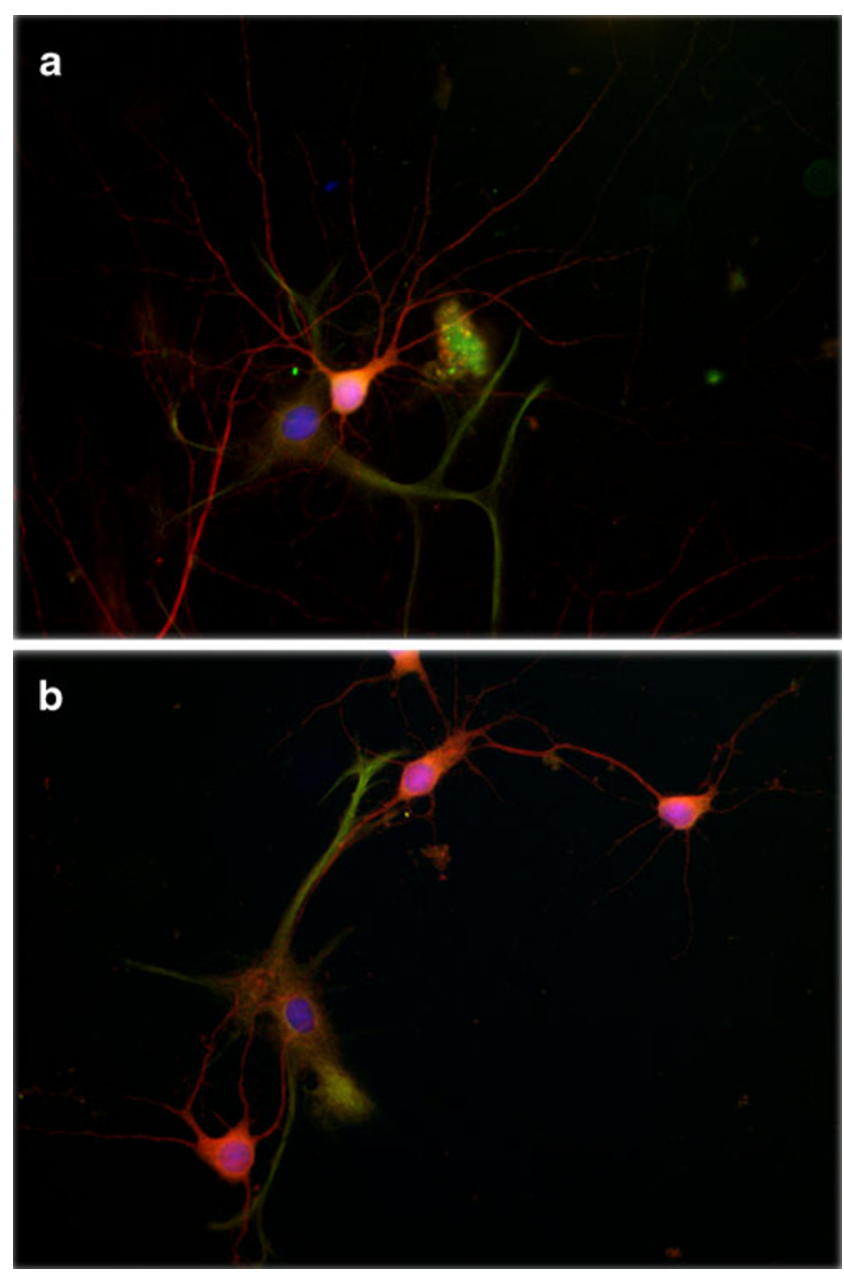

Fig. 1 Perinatal asphyxia reduces neurite branching of primary cultured pyramidal neurons from hippocampus. Asphyxia was induced by immersing foetuses-containing uterine horns, removed from ready-to-deliver rats into a water bath at $37^{\circ} \mathrm{C}$ for $21 \mathrm{~min}$. The cultures were prepared $6 \mathrm{~h}$ after delivery. After 14 days in vitro, the cultures were fixed with a formalin solution for assaying neuronal and astroglial phenotype using antibodies against microtubule associated protein-2 (MAP-2, red) and glial fibrillary acidic protein (GFAP, green) respectively, counterstained with 4',6-diamidino-2-phenylindole (DAPI, blue), a DNA marker. A fluorescent photomicrograph of cultures from a caesarean-delivered control (a), and asphyxia-exposed (b) rats, showing MAP-2 (red) and GPAP (green) positive cells is shown. A significant decrease on neurite branching is observed in asphyctic cultures (b), principally evident in neurites of secondary and tertiary order. Moreover, a relationship between neurons and astrocytes can be observed in both experimental conditions, being more pronounced in astrocytes from asphyctic condition. Scale bar: $20 \mu \mathrm{m}$. Taken from Rojas-Mancilla et al., in preparation

Oxidative stress is associated with inactivation of a number of enzymes, including mitochondrial respiratory enzymes $[69,99]$, low capacity of the antioxidant mechanism at this early developmental stage [100-103], high oxidative phosphorylation, high free iron producing hydroxyl radicals, high fatty acid content, high metabolism and low metabolic reserves, high oxygen consumption, and immaturity at birth $[8,102,104,105]$ (see Fig. 2). 


\section{Perinatal Asphyxia}

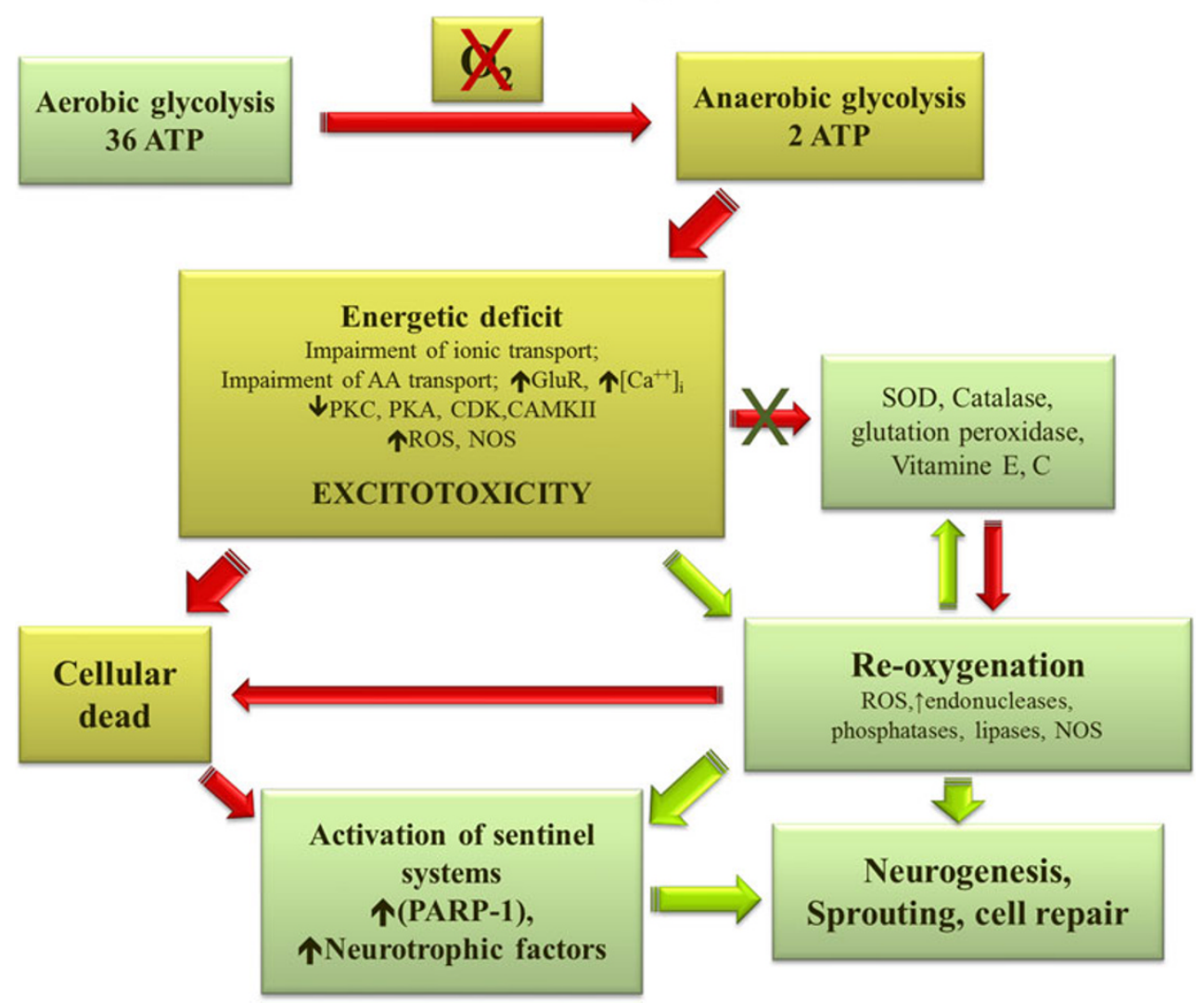

Fig. 2 Neuropathological mechanisms induced by perinatal asphyxia in the neonatal brain. Following PA, energy failure leads to a shift from aerobic to anaerobic metabolism, resulting in a decreased rate of ATP and other energy compounds, lactate accumulation, decreased $\mathrm{pH}$, and finally, over-production of reactive oxygen species (ROS). An ATP deficit leads to dissipation of ion gradients and membrane depolarisation, due to pumps decreased protein phosphorylation, with a subsequent increase in extracellular glutamate concentration. This results in over-activation of glutamate receptors inducing a massive influx of $\mathrm{Ca}^{2+}$ into cells, which activates proteases, lipases, endonucleases, and nitric oxide synthases that degrade the cytoskeleton and extracellular matrix proteins, producing membrane lipid peroxidation, peroxynitrites, and other free radicals. These events elicit a cascade of downstream intracellular processes that finally lead to excitotoxic

\section{Perinatal asphyxia and cell death}

The mechanisms of neuronal cell death after PA includes necrosis, apoptosis, autophagia and hybrid cell deaths and/ or a continuum of neuronal phenotypes, depending principally on the severity of the insult and the maturational state of the cell [69, 106-109]. An initial decrease in high-energy phosphates results in impairment of the ATP-dependent $\mathrm{Na}^{+}-\mathrm{K}^{+}$pump, which after the severe insult causes an acute influx of $\mathrm{Na}^{+}, \mathrm{Cl}^{-}$, and water with consequent cell swelling, cell lysis, and thus early cell death by necrosis. Conversely, a less severe insult causes membrane depolarisation followed by a cascade of excitotoxicity and oxidative neuronal damage and cell death. At the same time, antioxidative mechanisms get involved and DNA damage triggers the activation of sentinel proteins that maintain genome integrity, such as poly (ADPribose) polymerases (PARPs), but when overactivated, leads to further energy depletion and cell death. Depending upon time after asphyctic injury, re-oxygenation can lead to improper homeostasis, prolonging the energy deficit and/or generating oxidative stress. Oxidative stress has been associated with inactivation of a number of metabolic repair enzymes and further activation of degradatory enzymes, thus extending and maintaining damage. After acute damage, proliferation and sprouting are diminished, in agreement with a decrease in activity of Protein kinase C (PKC) and cyclin-dependent kinase (Cdk) observed after PA. But at long-term, release of neurotrophic factors promotes neurogenesis and neuritogenesis

stress, leading to delayed cell death, principally apoptosis. Thus, necrosis can be observed within minutes, while apoptosis takes more time to develop [110]. Apoptosis is triggered by the activation of endogenous proteases caspases, resulting in cytoskeletal disruption, cell shrinkage, and membrane blebbing. The nucleus undergoes chromatin condensation and nuclear DNA degradation resulting from endonuclease activation [111]. Since apoptosis requires energy, a determinant factor of when cells die is likely the ability of mitochondria to provide adequate energy. Another determinant of classic apoptosis is the loss of neuronal connections, which can continue days to weeks after injury, because groups of cells seem to commit to die 
[106]. Apoptosis is the more prevalent type of delayed cell death in the perinatal brain, and both caspase-dependent and caspase-independent mechanisms of apoptotic cell death have been recognised [43, 69, 83, 112, 113]. Thus, multiple cell death mediators are activated by neonatal $\mathrm{HI}$ injury, including various members of the Bcl-2, Bcl-2associated $\mathrm{X}$ protein (BAX), Bcl-2-associated death promoter (BAD) [43, 114, 115] death receptor [116], and caspases $[117,118]$ protein families, correlating with increased apoptosis in the brain $[119,120]$. After neonatal insult, markers of apoptosis (cleaved caspase-3) and necrosis (calpain-dependent fodrin breakdown product) can be expressed by the same damaged neurons [121], suggesting that the "continuum" could be explained by a failure of some dying cells to complete apoptosis, due to a lack of energy and mitochondrial dysfunction [106, 113, 122]. HI also increases markers for autophagosoma (microtubule-associated protein 1 light chain 3-11) and lysosomal activities (cathepsin $\mathrm{D}$, acid phosphatase, and $\beta$ $\mathrm{N}$-cetylhexosaminidase) in cortical and hippocampal CA3damaged neurons, suggesting an activation of autophagic flux that may be related to the apoptosis observed in delayed neuronal death after severe HI [84, 108].

Increased knowledge of the factors that determine when or how cells die after $\mathrm{HI}$ is important since it might be possible to salvage tissue using drugs, growth factors, or interventions that influence brain activity and restore the damaged neurocircuitry.

\section{Perinatal asphyxia and neurotransmission systems}

\section{Glutamatergic system}

The depletion of energy reserves that accompanies prolonged hypoxia results in neuronal depolarisation and the release of excitatory amino acids into the extracellular space $[69,123-126]$, in concentration that exceed both the glial reuptake capacity that is further compromised by energy failure [127] and re-uptake into the synaptic nerve terminal [128]. Thus, glutamate and aspartate accumulate to excitotoxic levels [86, 92-94]. Glutamate activates ionotropic NMDA, AMPA/KA and metabotropic receptors. AMPA/KA receptor activation increases sodium conductance, depolarising the membrane and activating voltagedependent calcium channels including the NMDA receptor channel. Metabotropic receptors mGluR1-mGluR5, through second messengers, mobilise calcium from intracellular reservoirs to the cytosolic compartment, activating proteases, lipases and endonucleases, which in turn initiate a process of cell death $[44,86,129,130]$. In fact, a transient increase in excitatory amino acid levels has been found in several experimental models of $\mathrm{HI}$ and in the cerebrospinal fluid of human newborn $[85,125,131,132]$. The importance of NMDA-mediated injury in the immature brain is related to the fact that NMDA receptors are functionally up regulated in the perinatal period because of their role in activity-dependent neuronal plasticity [94]. Immature NMDA channels has a higher probability of aperture and conductance than adult channels, and the voltage-dependent magnesium block that is normally present in adult channels at resting membrane potentials, is more easily relieved in the perinatal period $[84,133]$. Thus, increased expression and phosphorylation of NR1 subunits of NMDA receptors have been observed in the striatum after PA. This change is correlated with increased excitability and neurodegeneration during the neonatal period [134, 135]. Moreover, a deficiency in the GluR2 subunit of AMPARs during development has been correlated with increased susceptibility to $\mathrm{HI}$ at the regional and cellular levels [136, 137]. Recent studies further suggest crosstalk between inflammation and excitotoxic neuronal damage. It has been shown that the pro-inflammatory cytokine TNF- $\alpha$ is one of the most potent regulators of AMPAR trafficking to and from the plasma membrane, and that it can rapidly increase the proportion of $\mathrm{Ca}^{2+}$. permeable AMPAR at the surface. In combination with increased extracellular glutamate levels, this enhances excitotoxic cell death $[85,138]$.

The pharmacological blockade of glutamate receptors markedly protects against brain injury induced by severe hypoxia [139-142], reinforcing the idea that glutamatergic receptors during the perinatal period are most susceptible over-activation, promoting the excitotoxicity found after hypoxic ischaemic insults.

Astrocytes also play an important role in preventing neurotoxicity by glutamate uptake [143-147] and are affected by the energy deficit induced by PA as described earlier. Indeed, a decrease in glutamate uptake has been observed in the hippocampus of rat pups subjected to 15 min of PA [148] and a similar result has been observed in the cortex, basal ganglia and thalamus of piglets [149]. Reduced glutamate uptake is correlated with a downregulation of astrocytic excitatory amino acid transporters EAAT-1 and EAAT-2 [150] after HI, reinforcing the idea that energy deficits also promote a severe disruption of astrocytic cell function.

\section{Dopaminergic and nitridergic system}

Mesencephalic dopamine (DA) neurons are essential for the control of motor and cognitive behaviour, and are associated with multiple psychiatric and neurodegenerative disorders [151]. In recent years, increasing evidence shows that the monoamine neurotransmitters, particularly DA, may aggravate damage to the brain induced by HI. The 
striatum, a region richly innervated by the nigrostriatal dopaminergic pathway, is especially susceptible to asphyctic neuronal damage [47].

Levels of DA as well as its metabolites may remain elevated even after normoxia is stabilised [152], due to an impaired DA uptake mechanism [153, 154]. It has been suggested that during $\mathrm{HI}$, the increase in extracellular DA levels can result in alterations in the sensitivity of neurons to the excitatory amino acids [155, 156]. Furthermore, glutamate and aspartate levels are increased, mainly in mesencephalic tissues [70]. A proposed mechanism for the neurotoxic effect of DA is through an increase in the production of free radicals during the re-oxygenation period $[157,158]$. This is in agreement with evidence showing that neuronal injury occurring during re-oxygenation after an asphyctic insult is partly due to oxygen free radicalmediated oxidative events [159-161]. PA also induces change in the expression and pharmacological parameters of dopaminergic receptors in the meso-telencephalic DA systems [125]. In addition, asphyxia induced an increase of tyrosine hydroxylase (TH) mRNA in the projection fields, striatum and limbic regions, at 1 week. PA did not appear to exert any effect on $\mathrm{D}_{1} \mathrm{R}$ mRNA levels. These changes may affect $\mathrm{D}_{2} \mathrm{R}$ and $\mathrm{D}_{1} \mathrm{R}$ expression differently during development, contributing to long-term imbalances in neurocircuitry [162].

The postnatal establishment of DA neuronal connectivity can be disturbed by metabolic insults occurring at birth. Indeed, it has been shown that PA, alters the establishment of DA neurocircuitries, with long-term consequences. [163]. In our studies, we have shown decreased $\mathrm{TH}$ labelling, together with decreased cell viability in substantia nigra (SN) of hypoxic rat brains, suggesting an increased vulnerability of DA cells to hypoxic insult [90, 163]. It was reported that foetal asphyxia induced at E17 by 75-minute clamping of the uterine circulation causes long-term deficits in DA-mediated locomotion in rats, which was related to loss of dopaminergic neurons in the SN, probably associated with nigrostriatal astrogliosis [164]. The molecular changes in glial cell survival following PA are not fully established yet, and the resulting effects of astrocytic alterations on neuron survival and neurite outgrowth and branching should be determined.

In vivo, neuritogenesis depends on signals from neighbouring and distant cells to guide the growth cone to the targets [151, 163, 165]. The expression of guidance proteins such as semaphorins, ephrins, netrins, Slits and their cognate receptors and corresponding growth cones are likely the primary targets for the effect of metabolic insults on the CNS [151]. DA fibres start to invade the neostriatum before birth [166], but DA-containing axon terminals establish a mature targeting several weeks after birth [167]. In the neostriatum, TH immune-reactive fibres have been shown decrease after PA [62], and the dendrite branching of dopaminergic neurons evaluated in organotypic cultures show decreased secondary and higher order dendrite branching after asphyxia [90, 163]. These observations could indicate a modification in attractive and repulsive signals, perhaps suggesting a role for semaphorins, which have been shown to be particularly vulnerable to oxidative stress [168].

Furthermore, the neuronal nitric oxide synthase (nNOS) positive neurons in neostriatum show alterations after PA, evidenced by a decrease in number and complexity of neurite trees. It is interesting that in the $\mathrm{SN}$ the number of nNOS-positive neurons increases [89, 90], revealing that the interactions amongst DA and nNOS neurons in mesencephalon and telencephalon are regionally different [169, 170].

Finally, there are several studies indicating increased anxiety following PA [61]. Anxiety has been associated with the neurocircuitries involving neurons of the ventral hippocampus, the prefrontal cortex and amygdale that are regulated by dopaminergic innervation [171, 172]. Since the DA pathways have shown to be particularly vulnerable to PA $[62,70,90,162,173]$, it is tempting to hypothesise that the anxiety-like behaviour is linked to an impairment of DA transmission.

\section{Perinatal asphyxia and neuroinflammation}

Recently, the interconnection between the immune and neuronal systems has been a focus of several studies, especially in the context of pathogenesis, in which sustained or excessive inflammation has been associated with neurotoxicity and numerous neuropathologies [174-177].

One major hallmark of neuroimmflamation is the activation of microglia, which are resident parenchymal cells of the brain, derived from the same myeloid lineage as macrophages and dendritic cells [178]. If brain injury occurs, microglia activate, changing the pattern of secreted molecules and activating de novo synthesis of inflammation-related molecules [179]. Microglial activation has beneficial effects for the removal of cell debris, which attenuates inflammatory responses and promotes the remodelling of the affected area. However, over-activation of microglia can exacerbate neuronal death, because inflammatory molecules contribute to a detrimental environment, causing secondary damage [180]. Hence, the balance between a properly modulated or exacerbated immune response is fundamental for biological homeostasis.

Following HI, local inflammation is produced by activated microglia [181], probably due to necrotic cell death, producing a damage-associated molecular pattern (DAMPs). Toll-like receptors (TLRs) are expressed by 
microglial cells [175], sensing the DAMPs [182] and inducing the activation of the major transcription factor associated with inflammatory response, i.e. NF-KB (nuclear factor kappa-light-chain-enhancer of activated B cells). Following asphyctic injury, NF- $\mathrm{KB}$ is rapidly activated in neurons and glial cells $[183,184]$. Indeed, it has been shown that NF-kB p65 is up-regulated in the rat brain 10 min postPA [185]. An increase in the transcriptional function of NF$\mathrm{KB}$ due to microglia activation leads to the induction of several genes associated with the innate immune response, including proinflammatory cytokines such as: Tumoral necrosis factor- $\alpha$ (TNF- $\alpha$ ), Interleukin-1 beta (IL-1 $\beta$ ), Interleukin-6 (IL-6), Interleukin-10 (IL-10), Interferon gamma (INF- $\gamma$ ), and proteases such as matrix metalloproteinases 3 and 9 (MMP-3 and MMP-9) [186-189].

In humans, a relationship has been established between pro-inflammatory cytokine serum level and outcome for infants with PA. Infants who die or develop cerebral palsy had high plasma levels of pro-inflammatory cytokines as compared to infants with normal outcomes [190]. In agreement, blood levels of IL-1 $\beta$, IL- 6 and TNF- $\alpha$ are correlated with cerebral spinal fluid (CSF) levels of IL-1 $\beta$ in infants with HIE during the first $24 \mathrm{~h}$ of life [191]. Thus, cell damage during PA is associated with microgliamediated inflammation [192] and inflammatory markers may be useful in predictive diagnostics for PA-induced brain damage and clinical outcomes.

\section{Perinatal asphyxia and sentinel proteins}

PA negatively affects the integrity of the genome, triggering the activation of sentinel proteins that maintain genome integrity, such as poly (ADP-ribose) polymerases (PARPs) [193], X-Ray Cross Complementing Factor 1 (XRCC1), DNA ligase III $\alpha$ [194], DNA polymerase $\beta[195,196]$, Excision Repair Cross-Complementing Rodent Repair Group 2 (ERCC2) [185, 197, 198] and DNA-dependent protein kinases [199].

PARP-1 is a member of the nuclear chromatin-associated PARPs proteins. PARP-1 catalyses the formation of poly (ADP-ribose) polymers (pADPr) from nicotinamide adenine dinucleotide $\left(\mathrm{NAD}^{+}\right)$, releasing nicotinamide as a product $[200,201]$. pADPr is then transferred to glutamic acid or aspartic residues of acceptor proteins, modifying them post-translationally [201, 202].

When PARP-1 is activated, intracellular levels of pADPr increase about 10 to 500 times [201]. It has been proposed that DNA damage induces the binding of PARP-1 to DNA, promoting the recruitment of the DNA repair machinery [195, 203]. Activated PARP-1 acts as a transcription regulator, unravelling the superstructure of chromatin and regulating the transcriptional activity of various genes, including nitric oxide synthase, chemokines and integrins. Thus, PARP-1 is involved in the regulation of various processes, including DNA replication, repairment, transcription, mitosis, proteins degradation and inflammation [201].

Despite the beneficial effects of PARP-1 activation for important cellular functions, enhanced pADPr formation can be detrimental, leading to various forms of cell death [204]. Normally, in mild DNA damage, PARP facilitates DNA repair by interacting with DNA repair enzymes such as DNA polymerase, XRCC1 and DNA-dependent protein kinase, allowing cells to survive. When the DNA damage is irreparable, caspase-dependent cell death, mediated by caspase 3 and caspase 7, degrades PARP-1 into two fragments of 89 and $24 \mathrm{kDa}$ [205]. Therefore, the cell is eliminated by apoptosis. It has also been reported that the accumulation of pADPr promotes the release of AIF (Apoptosis-inducing factor) from the mitochondria, leading to cell death through caspase-independent apoptosis [201]. However, when DNA damage is severe, PARP-1 is over activated, depleting intracellular $\mathrm{NAD}^{+}$levels, and consequently ATP [68]. This energy-compromised state inhibits many cellular processes, including apoptosis, and promotes necrosis [206]. Severe DNA damage is usually triggered by a massive degree of oxidative stress triggered by reactive oxygen species such as peroxynitrite, hydroxyl and superoxide free radicals. Thus, the effect of PARP-1 activity depends greatly on the intensity of DNA damage.

Asphyctic injury is characterised by low energy availability, because of a lack of oxygen. In this context, PARP-1 over activation is especially critical for cell survival. Many asphyctic models suggest the importance of energy depletion in this clinical condition [207-209] and note that PARP-1 inhibitors can avoid excessive energy decreases $[91,210,211]$. Consistently, restoring $\mathrm{NAD}^{+}$can prevent changes induced by PARP-1 over-activation [193].

\section{Perinatal asphyxia and neurogenesis: endogenous brain rescue}

Several compensatory mechanisms, including neurogenesis, have been proposed as mediators of endogenously triggered protection against delayed cell death [120, 212-216]. Indeed, increased neurogenesis has been observed in brain regions affected by HI [120, 214, 217, 218], including DG, CA1 [43, 213, 219, 220], subventricular zone (SVZ) [221, 222], neostriatum [223] and neocortex [224, 225]. It has been suggested that new cells produced in SVZ can migrate to the lesioned regions [226-229], attracted by stromal cellderived migratory signalling. When the new cells arrive in the lesioned region, they form functional connections [223]. Basic fibroblast growth factor (bFGF) has been identified as 
a factor promoting cell survival and neurogenesis [229231], through activation of the MAPK (Mitogen-activated protein kinases)/extracellular signal-regulated kinases (ERK) pathway [43, 232]. Also, the expression of bFGF has been observed to be upregulated in DG and SVZ following PA [43, 222, 233, Espina-Marchant et al., in preparation]. Recently, we have reported evidence suggesting that bFGF, through activation of the MAPK/ERK pathway is one of the mechanisms involved in neurogenesis induced by PA [43, 61, Espina-Marchant et al., in preparation]. Several proteins have been identified as modulators of the transduction cascade elicited by bFGF receptors (FGFR) during embryogenesis, including Spry (Sprouty), Sef (similar expression to FGF) and FLRT3 (leucine-rich repeat trans-membrane protein) [234]. Spry and Sef provide inhibitory regulation, while FRLT3 stimulates the activation of FGFR and ERK [235]. Whether these pathways regulate the cellular response to injury postnatally is not yet known, but recent studies have shown that FLRT3, Sef, and Spry proteins are up regulated following PA, with specific temporal and regional patterns [Morales et al., in preparation]. Indeed, neurogenesis can be regulated by a large number of molecules, including growth and neurotrophic factors [236, 237], neurotransmitters, such as dopamine [238] and serotonin [239-241] and other factors still under characterisation.

Striatal dopamine de-afferentation has been reported to increase neurogenesis in the adult olfactory bulb [242], although the mechanism by which this occurs is still unknown. Furthermore, it has been shown that D2 and D3 dopamine receptor stimulation promotes proliferation of neural progenitor cells in both SVZ [243], and hippocampus [244] while D1 receptor stimulation has also been shown to modulate neurogenesis, but indirectly, via GABAergic neurons [245]. Dopaminergic fibres targeting the SVZ and hippocampus originate in mesencephalon $\left(\mathrm{SN}_{\mathrm{C}}\right.$ and VTA). These fibres establish anatomical and functional contacts with cell precursors that express DA receptors [238]. When treated with apomorphine, a nonselective DA receptor agonist [246] or a combination of D1 and D2 agonists [247], the synthesis and release of growth factors associated with neurogenesis, such as bFGF [246, 248], BDNF, epidermal growth factor (EGF), Nerve growth factor (NGF), ciliary neurotrophic factor (CNTF). CNTF and glial cell-derived neurotrophic factor (GDNF) is increased [237, 249-252], promoting cell proliferation [247]. To date, the role of different dopamine receptors in asphyxia-induced neurogenesis has not been characterised. The issue is however relevant, because indirect dopamine agonists are used for treating attention deficit hyperactivity disorder (ADHD), a disorder strongly associated with PA [253]. Furthermore, it is clear that the issue of specific DA receptors must be investigated, because receptor multiplic- ity exists, conveying different and, sometimes opposing responses [254]. Recently, using organotypic cultures from DG, we investigated whether DA receptors are involved in the modulation of neurogenesis induced by PA. When treated with apomorphine (Apo), there was an increase in the number of $\mathrm{BrdU}^{+}$cells (a mitosis marker) and $\mathrm{BrdU}^{+} /$ $\mathrm{MAP}^{+}$(neuronal marker) cells in DG organotypic cultures from asphyxia-exposed, but not from control rats. Since PA induces a decrease in DA levels and an increase in DA receptor mRNA expression in DA target regions, it is possible that the effect of Apo on neurogenesis is via DA receptors rendered supersensitive by the asphyctic insult. Supersensitive receptors could also be located on astrocytes, releasing growth and neurotrophic factors, or directly on neural stem cells, driving a neuronal phenotype. Therefore, further progress is needed in understanding the subjacent mechanisms involved in the modulation of neurogenesis after brain insults, in order to develop novel therapeutic strategies for restoring the damaged neurocircuitry.

\section{Emerging targets for early intervention and neuroprotection}

Although understanding of the pathophysiology of PA is gradually increasing, individual therapeutic options for preventing or mitigating the effects produced by the insult are limited. In the last years, therapies have focused in reducing the effects caused by secondary neuronal damage and restoring the functionality of neurocircuitry. Recent progress with several promising neuroprotective compounds has been focussed on the first phase of $\mathrm{HI}$ insult including channel blockage (anti-convulsant or antiexcitatory), anti-oxidation, anti-inflammation [255] and apoptosis inhibitors. In later phase PA injury therapies that target the promotion of neuronal regeneration by stimulation of neurotrophic properties of the neonatal brain using growth factors and stem cell transplantation show promise [256-258].

Hypothermia has also proven to be an effective treatment to reduce neuronal injury secondary to hypoxia in animal models [259-261] and is currently applied in the clinic [257, 262-264]. The protective effects of hypothermia have been associated with inhibition of proteases and calpain activation, loss of mitochondrial membrane potential and mitochondrial failure, free radical damage, lipid peroxidation and inflammation [257, 265]. In a recent systematic review and meta-analysis of the 13 clinical trials published to date, therapeutic hypothermia was associated with a highly reproducible reduction in the risk of the combined outcome of mortality or moderate-to-severe neurodevelopmental disability, severe cerebral palsy, cognitive delay, and 
psychomotor delay but had higher incidences of arrhythmia and thrombocytopenia in childhood. In agreement, randomised controlled trials have shown that mild therapeutic hypothermia $\left(\leq 34^{\circ} \mathrm{C}\right.$ head cooling) [266] with or without whole-body cooling [267], reduces death and disability in these infants when initiated within $6 \mathrm{~h}$ of birth [84, 268]. However, there is concern for a narrow therapeutic window [261] and the lack of a clear mechanism of action for the effect of hypothermia [63, 69, 259, 269]. Combining pharmacological interventions with moderate hypothermia is probably the next step to fight $\mathrm{HI}$ brain damage in the clinical setting. Indeed, improved neuroprotection in the asphyxiated newborn has reportedly when hypothermia has been combined with anticonvulsant or antiexcitatory drugs including phenobarbital [270, 271], topiramate [272, 273], levetiracetam [274], memantine [273], xenon [275], magnesium sulphate [276], and bumetanide [277]. Further studies should concentrate on more rational pharmacological strategies by determining the optimal time and dose to inhibit the various potentially destructive molecular pathways and/or to enhance endogenous repair while avoiding adverse effects. The dissemination of this new therapy will require improved identification of infants with HIE and regional commitment to allow these infants to be cared for in a timely manner. Continued assessment of long-term outcomes of patients enrolled in completed trials should be a key priority to confirm the long-term safety of hypothermia and other therapeutics interventions.

PARP-1 inhibition as a neuroprotection target is a relatively novel therapeutic strategy for HI but requires systematic characterisation of substances with inhibitory potential. It also requires evaluating the inhibitory potential of drugs already used in paediatrics, but for different indications. Ultrapotent novel PARP inhibitors are now being used in human clinical trials for reducing cell necrosis following stroke and/or myocardial infarction, and for down regulating multiple pathways of inflammation and tissue injury following circulatory shock, colitis or diabetic complications [278]. However, applying ultrapotent PARP inhibitors during development could be dangerous since it has been shown that PARP-1 is required for repair of damaged DNA and other important functions $[279,280]$. Therefore, it has been suggested that moderate PARP-1 inhibitors should be chosen for neuronal protection during development $[219,281]$. Several natural compounds have been investigated for possible protection against insults leading to over-activation of PARP-1. Nicotinamide, an amide of nicotinic acid (vitamin B3/niacin) has a broad spectrum of neuroprotective functions in a variety of health conditions [282-285]. Nicotinamide protects against oxidative stress [286, 287], ischaemic injury [288] and inflammation [289] by replacing the depletion of the NADH/ $\mathrm{NAD}+$ pair produced by PARP-1 after activation to repair hypoxic injury-induced DNA damage [283, 290]. We have reported that therapeutic doses of nicotinamide $(0.8 \mathrm{mmol} /$ $\mathrm{kg}$, i.p.) produced a long-lasting inhibition of PARP-1 activity measured in brain and heart from asphyxia-exposed and control rats [Allende-Castro et al., in preparation]. Nicotinamide prevents several of the long term changes induced by PA on monoamines, including changes in the number of nNOS $^{+}$cells, neurite length, and number of THpositive neurites, even if the treatment is delayed for $24 \mathrm{~h}$, suggesting a clinically relevant therapeutic window $[89,90$, 291, 292]. Moreover, nicotinamide also prevents the effects elicited by PA on apoptosis, working memory, anxiety and motor alterations [42, 61]. Thus, nicotinamide prevents, with a wide therapeutic window, long-term neuronal deficits induced by PA. Further, its pharmacodynamic properties provide advantages over more selective compounds, in particular its low potency in inhibiting PARP-1. This quality is useful if the compound is administered during the neonatal period, because the drug will only antagonise the effect of PARP-1 overactivation, without impairing normal DNA repair and cell proliferation. Furthermore, nicotinamide can constitute a lead for exploring compounds with a similar pharmacological profile. Some caffeine metabolites, but not caffeine itself, are inhibitors of PARP-1 at physiological concentrations, including theophylline $(1,3-$ dimethylxanthine) [219] and paraxanthine (1,7-dimethylxanthine) [281, 293]. We are particularly interested in testing the substituted benzamide (N-(1-ethyl-2-pyrrolidinylmethyl)-2-methoxy-5-sulphamoyl benzamide) and other benzamides currently in clinical use in paediatrics; and the xanthine analogues, 1,3-dimethylxanthine and 1,7-dimethylxanthine, that are, already used for different clinical applications.

As described, inflammation plays an important role in the excitooxidative cascade of injury in the perinatal period [107]. Antiinflammatory agents have been shown to be effective in the treatment of brain injury by blocking microglial activation and thereby, reducing brain levels of IL-1 $\beta$ [186]. Treatment with an NFkB inhibitor also provides substantial protection against neonatal HI by inhibiting apoptosis [255]. Similar results have been found using other antiinflammatory or antioxidant drugs, such as, minocycline [186], N acetyl cysteine (a glutathione precursor) [294], indomethacin [256], melatonin (a natural potent free radical scavenger activating antioxidant enzymes) [295], allopurinol (a xantine-oxidase inhibitor) [296], pomegranate polyphenols (antioxidant) [297], 2-iminobiotin (inhibitor of nitric oxide synthase) [255], and necrostatin 1 (specific inhibitor of necroptosis) [84, 258, 298].

Recent advances in regenerative medicine suggest that neurotrophic factors and/or stem cell transplantation may improve repair of the HI-damaged brain. Neurotrophic 
factors including insulin-like growth factor (IGF-1) [266, 299], NGF [300], BDNF [301] and bFGF [302] reduce long-term HI-induced brain damage and improve recovery of behaviour in immature rats. Several authors have also reported beneficial effects of stem cell transplantation [303309]. Several types of stem cells including neuronal stem cells (NSC), mesenchymal stem cells (MSC) [308, 310, 311] and haematopoietic stem cells (HSC) [305] have been transplanted in both neonatal and adult animal models of ischaemic brain damage, promoting functional as well as anatomical recovery [305, 307-309, 312, 313]. Regenerative effects of stem cell transplantation likely involve both replacement of damaged cells by exogenous cells as well as improvement of endogenous repair processes by releasing trophic factors [303, 308, 310, 311]. Indeed, a single hemispheric injection with MSC 10 days after HI induced an up regulation of genes involved in cell survival, proliferation and neurogenesis. Two injections of MSC induced expression of genes involved in cell proliferation, as well as, differentiation and network integration [308]. Intraperitoneal transplantation of human umbilical cord blood mononuclear cells (HUCB), $3 \mathrm{~h}$ after the HI insult, resulted in better performance of two developmental sensorimotor reflexes, in the first week after the injury [306]. Moreover, a neuroprotective effect in the striatum, and a decrease in the number of activated microglial cells in the cerebral cortex of treated animals were observed suggesting that HUCB transplantation might rescue striatal neurons from cell death after a neonatal $\mathrm{HI}$ injury resulting in better functional recovery [314]. Recently, the potential use of stem/progenitor cell therapies for neuroprotection or regeneration after neonatal $\mathrm{HI}$ has been evaluated in several preclinical studies, and the most promising results are now being tested in clinical trials [315].

\section{Conclusions \& outlook}

The present review addresses a clinically relevant problem with both paediatric and neuropsychiatric implications. PA is a main cause of newborn death and long-term neurological damage still without a predictive diagnostics, preventive and/or treatment of consensus.

An early diagnosis for predictive diagnostics of PA is of vital importance in planning the short- and long-term care of the infant. The emphasis in neonatology and paediatrics is on non-invasive diagnosis approaches for predictive diagnostics.

Advances in the diagnosis and early predictive biomarkers of PA outcome have been achieved, but still need improvement. Long-term follow-up studies are required to correlate the information obtained with the early predictive biomarkers and clinical-pathophysiological outcome.
Significant progress in understanding the pathophysiology of asphyxia is being achieving, providing a valuable framework on understanding the predisposition to develop metabolic, neuropsychiatric and neurodegenerative diseases at adult stages. It is expected that future studies will allow the identification of critical molecular, morphological, physiological and pharmacological parameters, specifying variables that should be considered when planning neonatal care and development programmes.

Emerging targets for early intervention and neuroprotection have been focussed on the inhibition of various potentially destructive molecular pathways including excitotoxicity, inflammation, oxidative stress and cell death, and/or therapies that target on restoring functionality of neurocircuitries by stimulation of neurotrophic endogenous properties of the neonatal brain using growth factors and stem cell transplantation. The use of these novel interventions alone or in combination is very attractive and needs further research.

In summary, the individual prediction, targeted prevention and personalised treatments of newborn with asphyctic deficits, is priority in neonatology and paediatrics care. Advanced strategies in development of robust diagnostic, biomarker and potential drug-targets approaches are the main goal for future research.

Acknowledgements We would like to grateful to Professor Andrew Tasker for critical and helpful comments on the manuscript. We thank Professor Mario Herrera-Marschitz for the valuable support and guideline. This work was supported by FONDECYT-Chile (1110263, 1080447 and 11070192), CONICYT/DAAD (137809529), Institute Millennium-BNI research grants, CONICYT PhD Fellows (PEM, MGH and ERM) and MECESUP (UCh0714) $\mathrm{PhD}$ Fellow (TNP).

\section{References}

1. Herrera-Marschitz M, Morales P, Leyton L, Bustamante D, Klawitter V, Espina-Marchant P, et al. Perinatal asphyxia: current status and approaches towards neuroprotective strategies, with focus on sentinel proteins. Neurotox Res. 2011;19:603-27.

2. MacLennan A. A template for defining a causal relation between acute intrapartum events and cerebral palsy: international consensus statement. BMJ. 1999;319:1054-9.

3. American College of Obstetrics and Gynecology., Task Force on Neonatal Encephalopathy and Cerebral Palsy., American Academy of Pediatrics. Neonatal Encephalopathy and Cerebral Palsy: Defining the Pathogenesis and Pathophysiology. Edited by Washington, DC, American College of Obstetricians and Gynecologists, 2003.

4. Sarnat HB, Sarnat MS. Neonatal encephalopathy following fetal distress. A clinical and electroencephalographic study. Arch Neurol. 1976;33:696-705.

5. Leuthner SR, Das UG. Low Apgar scores and the definition of birth asphyxia. Pediatr Clin North Am. 2004;51:737-45.

6. Berger R, Garnier Y. Perinatal brain injury. J Perinat Med. 2000;28:261-85. 
7. Volpe JJ. Perinatal brain injury: from pathogenesis to neuroprotection. Ment Retard Dev Disabil Res Rev. 2001;7:56-64.

8. Vannucci SJ, Hagberg H. Hypoxia-ischemia in the immature brain. J Exp Biol. 2004;207:3149-54.

9. Low JA, Robertson DM, Simpson LL. Temporal relationships of neuropathologic conditions caused by perinatal asphyxia. Am J Obstet Gynecol. 1989;160:608-14.

10. de Haan M, Wyatt JS, Roth S, Vargha-Khadem F, Gadian D, Mishkin M. Brain and cognitive-behavioural development after asphyxia at term birth. Dev Sci. 2006;9:350-8.

11. Kurinczuk JJ, White-Koning M, Badawi N. Epidemiology of neonatal encephalopathy and hypoxic-ischaemic encephalopathy. Early Hum Dev. 2010;86:329-38.

12. Lawn J, Shibuya K, Stein C. No cry at birth: global estimates of intrapartum stillbirths and intrapartum-related neonatal deaths. Bull World Health Organ. 2005;83:409-17.

13. Lawn JE, Kerber K, Enweronu-Laryea C, Cousens S. 3.6 million neonatal deaths - what is progressing and what is not? Semin Perinatol. 2010;34:371-86.

14. Wall SN, Lee AC, Carlo W, Goldenberg R, Niermeyer S, Darmstadt GL, et al. Reducing intrapartum-related neonatal deaths in low- and middle-income countries-what works? Semin Perinatol. 2010;34:395-407.

15. Prechtl HF, Einspieler C, Cioni G, Bos AF, Ferrari F, Sontheimer D. An early marker for neurological deficits after perinatal brain lesions. Lancet. 1997;349:1361-3.

16. Ferrari F, Todeschini A, Guidotti I, Martinez-Biarge M, Roversi MF, Berardi A, et al. General movements in full-term infants with perinatal asphyxia are related to basal ganglia and thalamic lesions. J Pediatr. 2011;158:904-11.

17. Martinez-Biarge M, Diez-Sebastian J, Rutherford MA, Cowan FM. Outcomes after central grey matter injury in term perinatal hypoxic-ischaemic encephalopathy. Early Hum Dev. 2010;86:675-82.

18. Cowan F, Rutherford M, Groenendaal F, Eken P, Mercuri E, Bydder GM, et al. Origin and timing of brain lesions in term infants with neonatal encephalopathy. Lancet. 2003;361:736-42.

19. Kumar A, Mittal R, Khanna HD, Basu S. Free radical injury and blood-brain barrier permeability in hypoxic-ischemic encephalopathy. Pediatrics. 2008;122:e722-7.

20. Karlsson M, Wiberg-Itzel E, Chakkarapani E, Blennow M, Winbladh B, Thoresen M. Lactate dehydrogenase predicts hypoxic ischaemic encephalopathy in newborn infants: a preliminary study. Acta Paediatr. 2010;99:1139-44.

21. Ramin SM, Gilstrap 3rd LC. Other factors/conditions associated with cerebral palsy. Semin Perinatol. 2000;24:196-9.

22. van Handel M, Swaab H, de Vries LS, Jongmans MJ. Long-term cognitive and behavioral consequences of neonatal encephalopathy following perinatal asphyxia: a review. Eur J Pediatr. 2007;166:645-54.

23. Bjorkman ST, Miller SM, Rose SE, Burke C, Colditz PB. Seizures are associated with brain injury severity in a neonatal model of hypoxia-ischemia. Neuroscience. 2010;166:157-67.

24. Maneru C, Junque C, Salgado-Pineda P, Serra-Grabulosa JM, Bartres-Faz D, Ramirez-Ruiz B, et al. Corpus callosum atrophy in adolescents with antecedents of moderate perinatal asphyxia. Brain Inj. 2003; 17:1003-9.

25. Maneru C, Junque C, Botet F, Tallada M, Guardia J. Neuropsychological long-term sequelae of perinatal asphyxia. Brain Inj. 2001;15:1029-39.

26. Odd DE, Lewis G, Whitelaw A, Gunnell D. Resuscitation at birth and cognition at 8 years of age: a cohort study. Lancet. 2009;373:1615-22.

27. Cannon TD, Yolken R, Buka S, Torrey EF. Decreased neurotrophic response to birth hypoxia in the etiology of schizophrenia. Biol Psychiatry. 2008;64:797-802.
28. Herrera-Marschitz M, Dell'Anna E, Andersson K, Lubec G. Is perinatal asphyxia a concurrent factor for the development of neuropsychiatric syndromes with clinical onset at late age stages? Rev Chil Neuro-Psiquiatr. 1999;37:108-16.

29. Sommer JU, Schmitt A, Heck M, Schaeffer EL, Fendt M, Zink M, et al. Differential expression of presynaptic genes in a rat model of postnatal hypoxia: relevance to schizophrenia. Eur Arch Psychiatry Clin Neurosci. 2010;260 Suppl 2:S819.

30. Basovich SN. The role of hypoxia in mental development and in the treatment of mental disorders: a review. Biosci Trends. 2010;4:288-96.

31. Cannon TD, Rosso IM, Hollister JM, Bearden CE, Sanchez LE, Hadley T. A prospective cohort study of genetic and perinatal influences in the etiology of schizophrenia. Schizophr Bull. 2000;26:351-66.

32. Zornberg GL, Buka SL, Tsuang MT. Hypoxic-ischemia-related fetal/neonatal complications and risk of schizophrenia and other nonaffective psychoses: a 19-year longitudinal study. Am J Psychiatr. 2000;157:196-202.

33. Dilenge ME, Majnemer A, Shevell MI. Long-term developmental outcome of asphyxiated term neonates. J Child Neurol. 2001;16:781-92.

34. Robertson C, Finer N. Term infants with hypoxic-ischemic encephalopathy: outcome at 3.5 years. Dev Med Child Neurol. 1985;27:473-84.

35. Robertson CM, Finer NN. Educational readiness of survivors of neonatal encephalopathy associated with birth asphyxia at term. J Dev Behav Pediatr. 1988;9:298-306.

36. Barnett A, Mercuri E, Rutherford M, Haataja L, Frisone MF, Henderson S, et al. Neurological and perceptual-motor outcome at 5-6 years of age in children with neonatal encephalopathy: relationship with neonatal brain MRI. Neuropediatrics. 2002;33:242-8.

37. Marlow N, Budge H. Prevalence, causes, and outcome at 2 years of age of newborn encephalopathy. Arch Dis Child Fetal Neonatal Ed. 2005;90:F193-4.

38. Robertson CM, Finer NN, Grace MG. School performance of survivors of neonatal encephalopathy associated with birth asphyxia at term. J Pediatr. 1989;114:753-60.

39. Wakuda T, Matsuzaki H, Suzuki K, Iwata Y, Shinmura C, Suda S, et al. Perinatal asphyxia reduces dentate granule cells and exacerbates methamphetamine-induced hyperlocomotion in adulthood. PLoS One. 2008;3:e3648.

40. Weitzdoerfer R, Pollak A, Lubec B. Perinatal asphyxia in the rat has lifelong effects on morphology, cognitive functions, and behavior. Semin Perinatol. 2004;28:249-56.

41. Calvert JW, Zhang JH. Pathophysiology of an hypoxic-ischemic insult during the perinatal period. Neurol Res. 2005;27:246-60.

42. Simola N, Bustamante D, Pinna A, Pontis S, Morales P, Morelli $\mathrm{M}$, et al. Acute perinatal asphyxia impairs non-spatial memory and alters motor coordination in adult male rats. Exp Brain Res. 2008;185:595-601.

43. Morales P, Fiedler JL, Andres S, Berrios C, Huaiquin P, Bustamante D, et al. Plasticity of hippocampus following perinatal asphyxia: effects on postnatal apoptosis and neurogenesis. J Neurosci Res. 2008;86:2650-62.

44. Pulsinelli WA, Brierley JB, Plum F. Temporal profile of neuronal damage in a model of transient forebrain ischemia. Ann Neurol. 1982;11:491-8.

45. Pasternak JF, Predey TA, Mikhael MA. Neonatal asphyxia: vulnerability of basal ganglia, thalamus, and brainstem. Pediatr Neurol. 1991;7:147-9.

46. Gunn AJ, Cook CJ, Williams CE, Johnston BM, Gluckman PD. Electrophysiological responses of the fetus to hypoxia and asphyxia. J Dev Physiol. 1991;16:147-53. 
47. Pastuszko A. Metabolic responses of the dopaminergic system during hypoxia in newborn brain. Biochem Med Metabol Biol. 1994;51:1-15.

48. Van Erp TG, Saleh PA, Rosso IM, Huttunen M, Lonnqvist J, Pirkola T, et al. Contributions of genetic risk and fetal hypoxia to hippocampal volume in patients with schizophrenia or schizoaffective disorder, their unaffected siblings, and healthy unrelated volunteers. Am J Psychiatr. 2002;159:1514-20.

49. Miller SP, Ramaswamy V, Michelson D, Barkovich AJ, Holshouser B, Wycliffe N, et al. Patterns of brain injury in term neonatal encephalopathy. J Pediatr. 2005;146:453-60.

50. Barkovich AJ, Miller SP, Bartha A, Newton N, Hamrick SE, Mukherjee P, et al. MR imaging, MR spectroscopy, and diffusion tensor imaging of sequential studies in neonates with encephalopathy. AJNR Am J Neuroradiol. 2006;27:533-47.

51. DeLong GR. Autism, amnesia, hippocampus, and learning. Neurosci Biobehav Rev. 1992;16:63-70.

52. Lou HC. Etiology and pathogenesis of attention-deficit hyperactivity disorder (ADHD): significance of prematurity and perinatal hypoxic-haemodynamic encephalopathy. Acta Paediatr. 1996;85:1266-71.

53. Rennie JM, Hagmann CF, Robertson NJ. Outcome after intrapartum hypoxic ischaemia at term. Semin Fetal Neonatal Med. 2007;12:398-407.

54. Johnston MV, Hoon Jr AH. Possible mechanisms in infants for selective basal ganglia damage from asphyxia, kernicterus, or mitochondrial encephalopathies. J Child Neurol. 2000;15:58891.

55. Stone BS, Zhang J, Mack DW, Mori S, Martin LJ, Northington FJ. Delayed neural network degeneration after neonatal hypoxiaischemia. Ann Neurol. 2008;64:535-46.

56. Lodygensky GA, West T, Moravec MD, Back SA, Dikranian K, Holtzman DM, et al. Diffusion characteristics associated with neuronal injury and glial activation following hypoxia-ischemia in the immature brain. Magn Reson Med. 2011; doi:10.1002/ mrm.22869.

57. Dell'Anna E, Chen Y, Engidawork E, Andersson K, Lubec G, Luthman J, et al. Delayed neuronal death following perinatal asphyxia in rat. Exp Brain Res. 1997;115:105-15.

58. Morales P, Reyes P, Klawitter V, Huaiquin P, Bustamante D, Fiedler J, et al. Effects of perinatal asphyxia on cell proliferation and neuronal phenotype evaluated with organotypic hippocampal cultures. Neuroscience. 2005;135:421-31.

59. Bjelke B, Andersson K, Ogren SO, Bolme P. Asphyctic lesion: proliferation of tyrosine hydroxylase-immunoreactive nerve cell bodies in the rat substantia nigra and functional changes in dopamine neurotransmission. Brain Res. 1991;543:1-9.

60. Johansen FF, Sorensen T, Tonder N, Zimmer J, Diemer NH. Ultrastructure of neurons containing somatostatin in the dentate hilus of the rat hippocampus after cerebral ischaemia, and a note on their commissural connections. Neuropathol Appl Neurobiol. 1992;18:145-57.

61. Morales P, Simola N, Bustamante D, Lisboa F, Fiedler J, Gebicke-Haerter PJ, et al. Nicotinamide prevents the longterm effects of perinatal asphyxia on apoptosis, non-spatial working memory and anxiety in rats. Exp Brain Res. 2010;202:1-14.

62. Kohlhauser C, Kaehler S, Mosgoeller W, Singewald N, Kouvelas $\mathrm{D}$, Prast $\mathrm{H}$, et al. Histological changes and neurotransmitter levels three months following perinatal asphyxia in the rat. Life Sci. 1999;64:2109-24.

63. Hoeger H, Engidawork E, Stolzlechner D, Bubna-Littitz H, Lubec B. Long-term effect of moderate and profound hypothermia on morphology, neurological, cognitive and behavioural functions in a rat model of perinatal asphyxia. Amino Acids. 2006;31:385-96.
64. Iuvone L, Geloso MC, Dell'Anna E. Changes in open field behavior, spatial memory, and hippocampal parvalbumin immunoreactivity following enrichment in rats exposed to neonatal anoxia. Exp Neurol. 1996;139:25-33.

65. Hoeger H, Engelmann M, Bernert G, Seidl R, Bubna-Littitz H, Mosgoeller W, et al. Long term neurological and behavioral effects of graded perinatal asphyxia in the rat. Life Sci. 2000;66:947-62.

66. Dell'Anna ME, Calzolari S, Molinari M, Iuvone L, Calimici R. Neonatal anoxia induces transitory hyperactivity, permanent spatial memory deficits and CA1 cell density reduction in developing rats. Behav Brain Res. 1991;45:125-34.

67. Lubec B, Chiappe-Gutierrez M, Hoeger H, Kitzmueller E, Lubec G. Glucose transporters, hexokinase, and phosphofructokinase in brain of rats with perinatal asphyxia. Pediatr Res. 2000;47:84-8.

68. Seidl R, Stockler-Ipsiroglu S, Rolinski B, Kohlhauser C, Herkner $\mathrm{KR}$, Lubec B, et al. Energy metabolism in graded perinatal asphyxia of the rat. Life Sci. 2000;67:421-35.

69. Herrera-Marschitz M, Morales P, Leyton L, Bustamante D, Klawitter V, Espina-Marchant P, et al. Perinatal asphyxia: current status and approaches towards neuroprotective strategies, with focus on sentinel proteins. Neurotox Res. 2011;19:603-27.

70. Chen Y, Engidawork E, Loidl F, Dell'Anna E, Goiny M, Lubec $\mathrm{G}$, et al. Short- and long-term effects of perinatal asphyxia on monoamine, amino acid and glycolysis product levels measured in the basal ganglia of the rat. Brain Res Dev Brain Res. 1997;104:19-30.

71. Dienel GA, Hertz L. Astrocytic contributions to bioenergetics of cerebral ischemia. Glia. 2005;50:362-88.

72. Engidawork E, Chen Y, Dell'Anna E, Goiny M, Lubec G, Ungerstedt $U$, et al. Effect of perinatal asphyxia on systemic and intracerebral $\mathrm{pH}$ and glycolysis metabolism in the rat. Exp Neurol. 1997;145:390-6.

73. Lubec B, Dell'Anna E, Fang-Kircher S, Marx M, HerreraMarschitz M, Lubec G. Decrease of brain protein kinase C, protein kinase $\mathrm{A}$, and cyclin-dependent kinase correlating with $\mathrm{pH}$ precedes neuronal death in neonatal asphyxia. J Investig Med. 1997;45:284-94.

74. Lubec B, Marx M, Herrera-Marschitz M, Labudova O, Hoeger $\mathrm{H}$, Gille L, et al. Decrease of heart protein kinase $\mathrm{C}$ and cyclindependent kinase precedes death in perinatal asphyxia of the rat. FASEB J. 1997;11:482-92.

75. Aronowski J, Grotta JC, Waxham MN. Ischemia-induced translocation of $\mathrm{Ca} 2+/$ calmodulin-dependent protein kinase II: potential role in neuronal damage. J Neurochem. 1992;58:174353.

76. Kretzschmar M, Glockner R, Klinger W. Glutathione levels in liver and brain of newborn rats: investigations of the influence of hypoxia and reoxidation on lipid peroxidation. Physiol Bohemoslov. 1990;39:257-60.

77. Hasegawa T. Anti-stress effect of beta-carotene. Ann N Y Acad Sci. 1993;691:281-3.

78. Ikeda T, Choi BH, Yee S, Murata Y, Quilligan EJ. Oxidative stress, brain white matter damage and intrauterine asphyxia in fetal lambs. Int J Dev Neurosci. 1999;17:1-14.

79. Tan S, Zhou F, Nielsen VG, Wang Z, Gladson CL, Parks DA. Increased injury following intermittent fetal hypoxiareoxygenation is associated with increased free radical production in fetal rabbit brain. J Neuropathol Exp Neurol. 1999;58:972-81.

80. Capani F, Loidl CF, Aguirre F, Piehl L, Facorro G, Hager A, et al. Changes in reactive oxygen species (ROS) production in rat brain during global perinatal asphyxia: an ESR study. Brain Res. 2001;914:204-7. 
81. Numagami Y, Zubrow AB, Mishra OP, Delivoria-Papadopoulos M. Lipid free radical generation and brain cell membrane alteration following nitric oxide synthase inhibition during cerebral hypoxia in the newborn piglet. J Neurochem. 1997;69:1542-7.

82. Berger R, Gjedde A, Heck J, Muller E, Krieglstein J, Jensen A. Extension of the 2-deoxyglucose method to the fetus in utero: theory and normal values for the cerebral glucose consumption in fetal guinea pigs. J Neurochem. 1994;63:271-9.

83. Dell'Anna E, Chen Y, Loidl F, Andersson K, Luthman J, Goiny $M$, et al. Short-term effects of perinatal asphyxia studied with Fos-immunocytochemistry and in vivo microdialysis in the rat. Exp Neurol. 1995;131:279-87.

84. Johnston MV, Fatemi A, Wilson MA, Northington F. Treatment advances in neonatal neuroprotection and neurointensive care. Lancet Neurol. 2011;10:372-82.

85. Holopainen IE, Lauren HB. Glutamate signaling in the pathophysiology and therapy of prenatal insults. Pharmacol Biochem Behav. 2011; doi:10.1016/j.pbb.2011.03.016.

86. Siesjö BK, Katsura K, Pahlmark K, Smith M-L. The multiples causes of ischemic brain damage: a speculative synthesis. In: Krieglstein J, Oberpichler-Schwenk H, editors. Pharmacology of cerebral ischemia. Stuttgart: Medpharm Scientific Publishers; 1992. p. 511-525

87. Kirino T. Delayed neuronal death. Neuropathology. 2000;20 (Suppl):S95-7.

88. Chen Z, Kontonotas D, Friedmann D, Pitts-Kiefer A, Frederick JR, Siman R, et al. Developmental status of neurons selectively vulnerable to rapidly triggered post-ischemic caspase activation. Neurosci Lett. 2005;376:166-70.

89. Klawitter V, Morales P, Bustamante D, Goiny M, HerreraMarschitz M. Plasticity of the central nervous system (CNS) following perinatal asphyxia: does nicotinamide provide neuroprotection? Amino Acids. 2006;31:377-84.

90. Klawitter V, Morales P, Bustamante D, Gomez-Urquijo S, Hokfelt T, Herrera-Marschitz M. Plasticity of basal ganglia neurocircuitries following perinatal asphyxia: effect of nicotinamide. Exp Brain Res. 2007;180:139-52.

91. Moroni F. Poly(ADP-ribose)polymerase 1 (PARP-1) and postischemic brain damage. Curr Opin Pharmacol. 2008;8:96-103.

92. Olney JW. Brain lesions, obesity, and other disturbances in mice treated with monosodium glutamate. Science. 1969;164:719-21.

93. Benveniste H, Drejer J, Schousboe A, Diemer NH. Elevation of the extracellular concentrations of glutamate and aspartate in rat hippocampus during transient cerebral ischemia monitored by intracerebral microdialysis. J Neurochem. 1984;43:1369-74.

94. McDonald JW, Johnston MV. Pharmacology of N-methyl-Daspartate-induced brain injury in an in vivo perinatal rat model. Synapse. 1990;6:179-88.

95. Peeters LL, Sheldon RE, Jones Jr MD, Makowski EL, Meschia G. Blood flow to fetal organs as a function of arterial oxygen content. Am J Obstet Gynecol. 1979;135:637-46.

96. Jensen A, Berger R. Fetal circulatory responses to oxygen lack. J Dev Physiol. 1991;16:181-207.

97. Berger R, Garnier Y. Pathophysiology of perinatal brain damage. Brain Res Brain Res Rev. 1999;30:107-34.

98. Lou HC, Tweed WA, Davies JM. Preferential blood flow increase to the brain stem in moderate neonatal hypoxia: reversal by naloxone. Eur J Pediatr. 1985;144:225-7.

99. Gitto E, Reiter RJ, Karbownik M, Tan DX, Gitto P, Barberi S, et al. Causes of oxidative stress in the pre- and perinatal period. Biol Neonate. 2002;81:146-57.

100. Mizui T, Kinouchi H, Chan PH. Depletion of brain glutathione by buthionine sulfoximine enhances cerebral ischemic injury in rats. Am J Physiol. 1992;262:H313-7.

101. Dringen R. Glutathione metabolism and oxidative stress in neurodegeneration. Eur J Biochem. 2000;267:4903.
102. Dringen R, Pawlowski PG, Hirrlinger J. Peroxide detoxification by brain cells. J Neurosci Res. 2005;79:157-65.

103. McQuillen PS, Ferriero DM. Selective vulnerability in the developing central nervous system. Pediatr Neurol. 2004;30:227-35.

104. Jensen A, Garnier Y, Middelanis J, Berger R. Perinatal brain damage - from pathophysiology to prevention. Eur J Obstet Gynecol Reprod Biol. 2003;110 Suppl 1:S70-9.

105. Erecinska M, Cherian S, Silver IA. Energy metabolism in mammalian brain during development. Prog Neurobiol. 2004;73:397-445.

106. Northington FJ, Zelaya ME, O'Riordan DP, Blomgren K, Flock $\mathrm{DL}$, Hagberg $\mathrm{H}$, et al. Failure to complete apoptosis following neonatal hypoxia-ischemia manifests as "continuum" phenotype of cell death and occurs with multiple manifestations of mitochondrial dysfunction in rodent forebrain. Neuroscience. 2007;149:822-33.

107. Hagberg H, Mallard C, Rousset CI, Xiaoyang W. Apoptotic mechanisms in the immature brain: involvement of mitochondria. J Child Neurol. 2009;24:1141-6.

108. Ginet V, Puyal J, Clarke PG, Truttmann AC. Enhancement of autophagic flux after neonatal cerebral hypoxia-ischemia and its region-specific relationship to apoptotic mechanisms. Am J Pathol. 2009;175:1962-74.

109. Eisenberg-Lerner A, Bialik S, Simon HU, Kimchi A. Life and death partners: apoptosis, autophagy and the cross-talk between them. Cell Death Differ. 2009;16:966-75.

110. Bonfoco E, Krainc D, Ankarcrona M, Nicotera P, Lipton SA. Apoptosis and necrosis: two distinct events induced, respectively, by mild and intense insults with N-methyl-D-aspartate or nitric oxide/superoxide in cortical cell cultures. Proc Natl Acad Sci USA. 1995;92:7162-6.

111. Yuan J, Yankner BA. Apoptosis in the nervous system. Nature. 2000;407:802-9.

112. Kirino T, Tamura A, Sano K. Selective vulnerability of the hippocampus to ischemia-reversible and irreversible types of ischemic cell damage. Prog Brain Res. 1985;63:39-58.

113. Northington FJ, Ferriero DM, Graham EM, Traystman RJ, Martin LJ. Early neurodegeneration after hypoxia-ischemia in neonatal rat is necrosis while delayed neuronal death is apoptosis. Neurobiol Dis. 2001;8:207-19.

114. Ness JM, Harvey CA, Strasser A, Bouillet P, Klocke BJ, Roth KA. Selective involvement of BH3-only Bcl-2 family members $\mathrm{Bim}$ and $\mathrm{Bad}$ in neonatal hypoxia-ischemia. Brain Res. 2006;1099:150-9.

115. Chen J, Zhu RL, Nakayama M, Kawaguchi K, Jin K, Stetler RA, et al. Expression of the apoptosis-effector gene, Bax, is upregulated in vulnerable hippocampal CA1 neurons following global ischemia. J Neurochem. 1996;67:64-71.

116. Graham EM, Sheldon RA, Flock DL, Ferriero DM, Martin LJ, O'Riordan DP, et al. Neonatal mice lacking functional Fas death receptors are resistant to hypoxic-ischemic brain injury. Neurobiol Dis. 2004;17:89-98.

117. Cheng Y, Black IB, DiCicco-Bloom E. Hippocampal granule neuron production and population size are regulated by levels of bFGF. Eur J Neurosci. 2002;15:3-12.

118. Golan H, Huleihel M. The effect of prenatal hypoxia on brain development: short- and long-term consequences demonstrated in rodent models. Dev Sci. 2006;9:338-49.

119. Ferrer I, Pozas E, Marti M, Blanco R, Planas AM. Methylazoxymethanol acetate-induced apoptosis in the external granule cell layer of the developing cerebellum of the rat is associated with strong c-Jun expression and formation of high molecular weight c-Jun complexes. J Neuropathol Exp Neurol. 1997;56:1-9.

120. Daval JL, Pourie G, Grojean S, Lievre V, Strazielle C, Blaise S, et al. Neonatal hypoxia triggers transient apoptosis followed by 
neurogenesis in the rat CA1 hippocampus. Pediatr Res. 2004;55:561-7.

121. Blomgren K, Zhu C, Wang X, Karlsson JO, Leverin AL, Bahr BA, et al. Synergistic activation of caspase-3 by m-calpain after neonatal hypoxia-ischemia: a mechanism of "pathological apoptosis"? J Biol Chem. 2001;276:10191-8.

122. Fatemi A, Wilson MA, Johnston MV. Hypoxic-ischemic encephalopathy in the term infant. Clin Perinatol. 2009;36:835-58. vii.

123. Novelli A, Reilly JA, Lysko PG, Henneberry RC. Glutamate becomes neurotoxic via the N-methyl-D-aspartate receptor when intracellular energy levels are reduced. Brain Res. 1988;451:205-12.

124. Choi DW. Glutamate neurotoxicity and diseases of the nervous system. Neuron. 1988;1:623-34.

125. Chen Y, Herrera-Marschitz M, Bjelke B, Blum M, Gross J, Andersson K. Perinatal asphyxia-induced changes in rat brain tyrosine hydroxylase-immunoreactive cell body number: effects of nicotine treatment. Neurosci Lett. 1997;221:77-80.

126. Johnston MV. Cellular alterations associated with perinatal asphyxia. Clin Invest Med. 1993;16:122-32.

127. Yeh TH, Hwang HM, Chen JJ, Wu T, Li AH, Wang HL. Glutamate transporter function of rat hippocampal astrocytes is impaired following the global ischemia. Neurobiol Dis. 2005; 18:476-83.

128. Silverstein F, Johnston MV. Effects of hypoxia-ischemia on monoamine metabolism in the immature brain. Ann Neurol. 1984;15:342-7.

129. Rothman SM, Olney JW. Glutamate and the pathophysiology of hypoxic-ischemic brain damage. Ann Neurol. 1986;19:105-11.

130. Chen HL, Pistollato F, Hoeppner DJ, Ni HT, McKay RD, Panchision DM. Oxygen tension regulates survival and fate of mouse central nervous system precursors at multiple levels. Stem Cells. 2007;25:2291-301.

131. Riikonen RS, Kero PO, Simell OG. Excitatory amino acids in cerebrospinal fluid in neonatal asphyxia. Pediatr Neurol. 1992;8:37-40.

132. Hagberg H, Thornberg E, Blennow M, Kjellmer I, Lagercrantz $\mathrm{H}$, Thiringer $\mathrm{K}$, et al. Excitatory amino acids in the cerebrospinal fluid of asphyxiated infants: relationship to hypoxic-ischemic encephalopathy. Acta Paediatr. 1993;82:925-9.

133. Monyer H, Burnashev N, Laurie DJ, Sakmann B, Seeburg PH. Developmental and regional expression in the rat brain and functional properties of four NMDA receptors. Neuron. 1994;12:529-40.

134. Guerguerian AM, Brambrink AM, Traystman RJ, Huganir RL, Martin LJ. Altered expression and phosphorylation of N-methylD-aspartate receptors in piglet striatum after hypoxia-ischemia. Brain Res Mol Brain Res. 2002;104:66-80.

135. Mueller-Burke D, Koehler RC, Martin LJ. Rapid NMDA receptor phosphorylation and oxidative stress precede striatal neurodegeneration after hypoxic ischemia in newborn piglets and are attenuated with hypothermia. Int $\mathrm{J}$ Dev Neurosci. 2008;26:67-76.

136. Sanchez RM, Koh S, Rio C, Wang C, Lamperti ED, Sharma D, et al. Decreased glutamate receptor 2 expression and enhanced epileptogenesis in immature rat hippocampus after perinatal hypoxia-induced seizures. J Neurosci. 2001;21:8154-63.

137. Talos DM, Fishman RE, Park H, Folkerth RD, Follett PL, Volpe JJ, et al. Developmental regulation of alpha-amino-3-hydroxy-5methyl-4-isoxazole-propionic acid receptor subunit expression in forebrain and relationship to regional susceptibility to hypoxic/ ischemic injury. I. Rodent cerebral white matter and cortex. J Comp Neurol. 2006;497:42-60.

138. Beattie MS, Ferguson AR, Bresnahan JC. AMPA-receptor trafficking and injury-induced cell death. Eur $\mathrm{J}$ Neurosci. 2010;32:290-7.
139. Silverstein FS, Torke L, Barks J, Johnston MV. Hypoxiaischemia produces focal disruption of glutamate receptors in developing brain. Brain Res. 1987;431:33-9.

140. McDonald JW, Silverstein FS, Johnston MV. MK-801 protects the neonatal brain from hypoxic-ischemic damage. Eur J Pharmacol. 1987;140:359-61.

141. Ford LM, Sanberg PR, Norman AB, Fogelson MH. MK-801 prevents hippocampal neurodegeneration in neonatal hypoxicischemic rats. Arch Neurol. 1989;46:1090-6.

142. Volbracht $C$, van Beek J, Zhu C, Blomgren K, Leist M. Neuroprotective properties of memantine in different in vitro and in vivo models of excitotoxicity. Eur $\mathrm{J}$ Neurosci. 2006;23:2611-22.

143. Bergles DE, Jahr CE. Synaptic activation of glutamate transporters in hippocampal astrocytes. Neuron. 1997;19:1297-308.

144. Carmignoto G. Reciprocal communication systems between astrocytes and neurones. Prog Neurobiol. 2000;62:561-81.

145. Domingues AM, Taylor M, Fern R. Glia as transmitter sources and sensors in health and disease. Neurochem Int. 2010;57:359 66.

146. Hamilton NB, Attwell D. Do astrocytes really exocytose neurotransmitters? Nat Rev Neurosci. 2010;11:227-38.

147. Halassa MM, Haydon PG. Integrated brain circuits: astrocytic networks modulate neuronal activity and behavior. Annu Rev Physiol. 2010;72:335-55.

148. Frizzo JK, Cardoso MP, de Assis AM, Perry ML, Volonte C, Frizzo ME. Effects of acute perinatal asphyxia in the rat hippocampus. Cell Mol Neurobiol. 2010;30:683-92.

149. Jantzie LL, Cheung PY, Johnson ST, Bigam DL, Todd KG. Cerebral amino acid profiles after hypoxia-reoxygenation and $\mathrm{N}$ acetylcysteine treatment in the newborn piglet. Neonatology. 2010;97:195-203.

150. Dallas M, Boycott HE, Atkinson L, Miller A, Boyle JP, Pearson HA, et al. Hypoxia suppresses glutamate transport in astrocytes. J Neurosci. 2007;27:3946-55.

151. Van den Heuvel DM, Pasterkamp RJ. Getting connected in the dopamine system. Prog Neurobiol. 2008;85:75-93.

152. Broderick PA, Gibson GE. Dopamine and serotonin in rat striatum during in vivo hypoxic-hypoxia. Metab Brain Dis. 1989;4:143-53.

153. Akiyama Y, Ito A, Koshimura K, Ohue T, Yamagata S, Miwa S, et al. Effects of transient forebrain ischemia and reperfusion on function of dopaminergic neurons and dopamine reuptake in vivo in rat striatum. Brain Res. 1991;561:120-7.

154. Akiyama Y, Koshimura K, Ohue T, Lee K, Miwa S, Yamagata S, et al. Effects of hypoxia on the activity of the dopaminergic neuron system in the rat striatum as studied by in vivo brain microdialysis. J Neurochem. 1991;57:997-1002.

155. Knapp AG, Dowling JE. Dopamine enhances excitatory amino acid-gated conductances in cultured retinal horizontal cells. Nature. 1987;325:437-9.

156. Globus MY, Busto R, Dietrich WD, Martinez E, Valdes I, Ginsberg MD. Effect of ischemia on the in vivo release of striatal dopamine, glutamate, and gamma-aminobutyric acid studied by intracerebral microdialysis. J Neurochem. 1988;51:1455-64.

157. Saugstad OD. Hypoxanthine as an indicator of hypoxia: its role in health and disease through free radical production. Pediatr Res. 1988;23:143-50.

158. Goplerud JM, Mishra OP, Delivoria-Papadopoulos M. Brain cell membrane dysfunction following acute asphyxia in newborn piglets. Biol Neonate. 1992;61:33-41.

159. Floyd RA. Role of oxygen free radicals in carcinogenesis and brain ischemia. FASEB J. 1990;4:2587-97.

160. Olano M, Song D, Murphy S, Wilson DF, Pastuszko A. Relationships of dopamine, cortical oxygen pressure, and hydroxyl radicals in brain of newborn piglets during hypoxia and posthypoxic recovery. J Neurochem. 1995;65:1205-12. 
161. Halliwell B, Gutteridge JM. The importance of free radicals and catalytic metal ions in human diseases. Mol Aspects Med. 1985;8:89-193.

162. Gross J, Andersson K, Chen Y, Muller I, Andreeva N, HerreraMarschitz M. Effect of perinatal asphyxia on tyrosine hydroxylase and D2 and D1 dopamine receptor mRNA levels expressed during early postnatal development in rat brain. Brain Res Mol Brain Res. 2005;134:275-81.

163. Morales P, Klawitter V, Johansson S, Huaiquin P, Barros VG, Avalos AM, et al. Perinatal asphyxia impairs connectivity and dopamine neurite branching in organotypic triple culture from rat substantia nigra, neostriatum and neocortex. Neurosci Lett. 2003;348:175-9.

164. Strackx E, Van den Hove DL, Steinbusch HP, Steinbusch HW, Vles JS, Blanco CE, et al. A combined behavioral and morphological study on the effects of fetal asphyxia on the nigrostriatal dopaminergic system in adult rats. Exp Neurol. 2008;211:413-22.

165. Derijck AA, Van Erp S, Pasterkamp RJ. Semaphorin signaling: molecular switches at the midline. Trends Cell Biol. 2010;20:568-76.

166. Seiger A, Olson L. Late prenatal ontogeny of central monoamine neurons in the rat: Fluorescence histochemical observations. Z Anat Entwicklungsgesch. 1973;140:281-318.

167. Antonopoulos J, Dori I, Dinopoulos A, Chiotelli M, Parnavelas JG. Postnatal development of the dopaminergic system of the striatum in the rat. Neuroscience. 2002;110:245-56.

168. Pasterkamp RJ, Kolodkin AL. Semaphorin junction: making tracks toward neural connectivity. Curr Opin Neurobiol. 2003;13:79-89.

169. Herrera-Marschitz M, Kohlhauser C, Gomez-Urquijo S, Ubink R, Goiny M, Hokfelt T. Excitatory amino acids, monoamine, and nitric oxide synthase systems in organotypic cultures: biochemical and immunohistochemical analysis. Amino Acids. 2000;19:33-43.

170. Gomez-Urquijo SM, Hokfelt T, Ubink R, Lubec G, HerreraMarschitz M. Neurocircuitries of the basal ganglia studied in organotypic cultures: focus on tyrosine hydroxylase, nitric oxide synthase and neuropeptide immunocytochemistry. Neuroscience. 1999;94:1133-51.

171. Sanders MJ, Wiltgen BJ, Fanselow MS. The place of the hippocampus in fear conditioning. Eur $\mathrm{J}$ Pharmacol. 2003;463:217-23.

172. Kalisch R, Schubert M, Jacob W, Kessler MS, Hemauer R, Wigger A, et al. Anxiety and hippocampus volume in the rat. Neuropsychopharmacology. 2006;31:925-32.

173. Klawitter V, Morales P, Johansson S, Bustamante D, Goiny M, Gross $\mathrm{J}$, et al. Effects of perinatal asphyxia on cell survival, neuronal phenotype and neurite growth evaluated with organotypic triple cultures. Amino Acids. 2005;28:149-55.

174. Ziebell JM, Morganti-Kossmann MC. Involvement of pro- and antiinflammatory cytokines and chemokines in the pathophysiology of traumatic brain injury. Neurotherapeutics. 2010;7:22-30.

175. Lehnardt S, Lehmann S, Kaul D, Tschimmel K, Hoffmann O, Cho S, et al. Toll-like receptor 2 mediates CNS injury in focal cerebral ischemia. J Neuroimmunol. 2007;190:28-33.

176. Glass CK, Saijo K, Winner B, Marchetto MC, Gage FH. Mechanisms underlying inflammation in neurodegeneration. Cell. 2010;140:918-34.

177. Tracey KJ. Physiology and immunology of the cholinergic antiinflammatory pathway. J Clin Invest. 2007;117:289-96.

178. Greaves DR, Gordon S. Macrophage-specific gene expression: current paradigms and future challenges. Int $\mathrm{J}$ Hematol. 2002;76:6-15.

179. Monif M, Burnstock G, Williams DA. Microglia: proliferation and activation driven by the $\mathrm{P} 2 \mathrm{X} 7$ receptor. Int $\mathrm{J}$ Biochem Cell Biol. 2010;42:1753-6.
180. Harry GJ, Kraft AD. Neuroinflammation and microglia: considerations and approaches for neurotoxicity assessment. Expert Opin Drug Metab Toxicol. 2008;4:1265-77.

181. Giulian D, Vaca K. Inflammatory glia mediate delayed neuronal damage after ischemia in the central nervous system. Stroke. 1993;24:I84-90.

182. Hermoso MA, Cidlowski JA. Putting the brake on inflammatory responses: the role of glucocorticoids. IUBMB Life. 2003;55:497-504.

183. Clemens JA, Stephenson DT, Yin T, Smalstig EB, Panetta JA, Little SP. Drug-induced neuroprotection from global ischemia is associated with prevention of persistent but not transient activation of nuclear factor-kappaB in rats. Stroke. 1998;29:677-82.

184. Herrmann O, Baumann B, de Lorenzi R, Muhammad S, Zhang $\mathrm{W}$, Kleesiek J, et al. IKK mediates ischemia-induced neuronal death. Nat Med. 2005;11:1322-9.

185. Lubec B, Labudova O, Hoeger H, Kirchner L, Lubec G. Expression of transcription factors in the brain of rats with perinatal asphyxia. Biol Neonate. 2002;81:266-78.

186. Buller KM, Carty ML, Reinebrant HE, Wixey JA. Minocycline: a neuroprotective agent for hypoxic-ischemic brain injury in the neonate? J Neurosci Res. 2009;87:599-608.

187. Battista D, Ferrari CC, Gage FH, Pitossi FJ. Neurogenic niche modulation by activated microglia: transforming growth factor beta increases neurogenesis in the adult dentate gyrus. Eur $\mathrm{J}$ Neurosci. 2006;23:83-93.

188. Hanisch UK, Kettenmann H. Microglia: active sensor and versatile effector cells in the normal and pathologic brain. Nat Neurosci. 2007;10:1387-94.

189. Girard S, Kadhim H, Roy M, Lavoie K, Brochu ME, Larouche A, et al. Role of perinatal inflammation in cerebral palsy. Pediatr Neurol. 2009; 40:168-74.

190. Foster-Barber A, Dickens B, Ferriero DM. Human perinatal asphyxia: correlation of neonatal cytokines with MRI and outcome. Dev Neurosci. 2001;23:213-8.

191. Aly H, Khashaba MT, El-Ayouty M, El-Sayed O, Hasanein BM. IL-1beta, IL-6 and TNF-alpha and outcomes of neonatal hypoxic ischemic encephalopathy. Brain Dev. 2006;28:178-82.

192. Deng W. Neurobiology of injury to the developing brain. Nat Rev Neurol. 2010;6:328-36.

193. Alano CC, Ying W, Swanson RA. Poly(ADP-ribose) polymerase1-mediated cell death in astrocytes requires $\mathrm{NAD}+$ depletion and mitochondrial permeability transition. J Biol Chem. 2004;279:18895-902.

194. Leppard JB, Dong Z, Mackey ZB, Tomkinson AE. Physical and functional interaction between DNA ligase IIIalpha and poly (ADP-Ribose) polymerase 1 in DNA single-strand break repair. Mol Cell Biol. 2003;23:5919-27.

195. Mishra OP, Akhter W, Ashraf QM, Delivoria-Papadopoulos M. Hypoxia-induced modification of poly (ADP-ribose) polymerase and dna polymerase beta activity in cerebral cortical nuclei of newborn piglets: role of nitric oxide. Neuroscience. 2003;119:1023-32.

196. Wilson SH. Mammalian base excision repair and DNA polymerase beta. Mutat Res. 1998;407:203-15.

197. Chiappe-Gutierrez M, Kitzmueller E, Labudova O, Fuerst G, Hoeger H, Hardmeier R, et al. mRNA levels of the hypoxia inducible factor (HIF-1) and DNA repair genes in perinatal asphyxia of the rat. Life Sci. 1998;63:1157-67.

198. Sung P, Bailly V, Weber C, Thompson LH, Prakash L, Prakash S. Human xeroderma pigmentosum group D gene encodes a DNA helicase. Nature. 1993;365:852-5.

199. de Murcia G, Menissier de Murcia J. Poly(ADP-ribose) polymerase: a molecular nick-sensor. Trends Biochem Sci. 1994;19:172-6. 
200. Hortobagyi T, Gorlach C, Benyo Z, Lacza Z, Hortobagyi S, Wahl $\mathrm{M}$, et al. Inhibition of neuronal nitric oxide synthase-mediated activation of poly(ADP-ribose) polymerase in traumatic brain injury: neuroprotection by 3-aminobenzamide. Neuroscience. 2003;121:983-90.

201. Altmeyer M, Hottiger MO. Poly(ADP-ribose) polymerase 1 at the crossroad of metabolic stress and inflammation in aging. Aging (Albany NY). 2009;1:458-69.

202. Poitras MF, Koh DW, Yu SW, Andrabi SA, Mandir AS, Poirier $\mathrm{GG}$, et al. Spatial and functional relationship between poly(ADPribose) polymerase-1 and poly(ADP-ribose) glycohydrolase in the brain. Neuroscience. 2007;148:198-211.

203. Rouleau M, Patel A, Hendzel MJ, Kaufmann SH, Poirier GG. PARP inhibition: PARP1 and beyond. Nat Rev Cancer. 2010;10:293-301.

204. Haile WB, Echeverry R, Wu F, Guzman J, An J, Wu J, et al. Tumor necrosis factor-like weak inducer of apoptosis and fibroblast growth factor-inducible 14 mediate cerebral ischemiainduced poly(ADP-ribose) polymerase-1 activation and neuronal death. Neuroscience. 2010;171:1256-64.

205. D'Amours D, Sallmann FR, Dixit VM, Poirier GG. Gain-offunction of poly(ADP-ribose) polymerase-1 upon cleavage by apoptotic proteases: implications for apoptosis. J Cell Sci. 2001;114:3771-8.

206. Burkle A. Physiology and pathophysiology of poly(ADPribosyl)ation. Bioessays. 2001;23:795-806.

207. Lorek A, Takei Y, Cady EB, Wyatt JS, Penrice J, Edwards AD, et al. Delayed ("secondary") cerebral energy failure after acute hypoxia-ischemia in the newborn piglet: continuous 48-hour studies by phosphorus magnetic resonance spectroscopy. Pediatr Res. 1994;36:699-706.

208. Yoles E, Zarchin N, Zurovsky Y, Mayevsky A. Metabolic and ionic responses to global brain ischemia in the newborn dog in vivo: II. Post-natal age aspects. Neurol Res. 2000;22:623-9.

209. Mayevsky A, Rogatsky GG. Mitochondrial function in vivo evaluated by NADH fluorescence: from animal models to human studies. Am J Physiol Cell Physiol. 2007;292:C615-40.

210. Szabo C. Cardioprotective effects of poly(ADP-ribose) polymerase inhibition. Pharmacol Res. 2005;52:34-43.

211. Grupp IL, Jackson TM, Hake P, Grupp G, Szabo C. Protection against hypoxia-reoxygenation in the absence of poly (ADPribose) synthetase in isolated working hearts. J Mol Cell Cardiol. 1999;31:297-303.

212. Yagita Y, Kitagawa K, Ohtsuki T, Takasawa K, Miyata T, Okano $\mathrm{H}$, et al. Neurogenesis by progenitor cells in the ischemic adult rat hippocampus. Stroke. 2001;32:1890-6.

213. Nakatomi H, Kuriu T, Okabe S, Yamamoto S, Hatano O, Kawahara N, et al. Regeneration of hippocampal pyramidal neurons after ischemic brain injury by recruitment of endogenous neural progenitors. Cell. 2002;110:429-41.

214. Kee NJ, Preston E, Wojtowicz JM. Enhanced neurogenesis after transient global ischemia in the dentate gyrus of the rat. Exp Brain Res. 2001;136:313-20.

215. Jin K, Minami M, Lan JQ, Mao XO, Batteur S, Simon RP, et al. Neurogenesis in dentate subgranular zone and rostral subventricular zone after focal cerebral ischemia in the rat. Proc Natl Acad Sci USA. 2001;98:4710-5.

216. Zhao C, Deng W, Gage FH. Mechanisms and functional implications of adult neurogenesis. Cell. 2008;132:645-60.

217. Bartley J, Soltau T, Wimborne H, Kim S, Martin-Studdard A, Hess D, et al. BrdU-positive cells in the neonatal mouse hippocampus following hypoxic-ischemic brain injury. BMC Neurosci. 2005;6:15.

218. Fagel DM, Ganat Y, Silbereis J, Ebbitt T, Stewart W, Zhang H, et al. Cortical neurogenesis enhanced by chronic perinatal hypoxia. Exp Neurol. 2006;199:77-91.
219. Moonen HJ, Geraets L, Vaarhorst A, Bast A, Wouters EF, Hageman GJ. Theophylline prevents NAD+ depletion via PARP1 inhibition in human pulmonary epithelial cells. Biochem Biophys Res Commun. 2005;338:1805-10.

220. Morales P, Huaiquin P, Bustamante D, Fiedler J, HerreraMarschitz M. Perinatal asphyxia induces neurogenesis in hippocampus: an organotypic culture study. Neurotox Res. 2007;12:81-4.

221. Ong J, Plane JM, Parent JM, Silverstein FS. Hypoxic-ischemic injury stimulates subventricular zone proliferation and neurogenesis in the neonatal rat. Pediatr Res. 2005;58:600-6.

222. Plane JM, Liu R, Wang TW, Silverstein FS, Parent JM. Neonatal hypoxic-ischemic injury increases forebrain subventricular zone neurogenesis in the mouse. Neurobiol Dis. 2004;16:585-95.

223. Kokaia Z, Thored P, Arvidsson A, Lindvall O. Regulation of stroke-induced neurogenesis in adult brain-recent scientific progress. Cereb Cortex. 2006;16 Suppl 1:i162-7.

224. Lichtenwalner RJ, Parent JM. Adult neurogenesis and the ischemic forebrain. J Cereb Blood Flow Metab. 2006;26:1-20.

225. Richardson RM, Sun D, Bullock MR. Neurogenesis after traumatic brain injury. Neurosurg Clin N Am. 2007;18:169-81. xi.

226. Doetsch F, Garcia-Verdugo JM, Alvarez-Buylla A. Cellular composition and three-dimensional organization of the subventricular germinal zone in the adult mammalian brain. J Neurosci. 1997; 17:5046-61.

227. Bedard A, Gravel C, Parent A. Chemical characterization of newly generated neurons in the striatum of adult primates. Exp Brain Res. 2006;170:501-12.

228. Collin T, Arvidsson A, Kokaia Z, Lindvall O. Quantitative analysis of the generation of different striatal neuronal subtypes in the adult brain following excitotoxic injury. Exp Neurol. 2005;195:71-80.

229. Lemasson M, Saghatelyan A, Olivo-Marin JC, Lledo PM. Neonatal and adult neurogenesis provide two distinct populations of newborn neurons to the mouse olfactory bulb. J Neurosci. 2005;25:6816-25.

230. Takami K, Iwane M, Kiyota Y, Miyamoto M, Tsukuda R, Shiosaka S. Increase of basic fibroblast growth factor immunoreactivity and its mRNA level in rat brain following transient forebrain ischemia. Exp Brain Res. 1992;90:1-10.

231. Ganat Y, Soni S, Chacon M, Schwartz ML, Vaccarino FM. Chronic hypoxia up-regulates fibroblast growth factor ligands in the perinatal brain and induces fibroblast growth factorresponsive radial glial cells in the sub-ependymal zone. Neuroscience. 2002;112:977-91.

232. Mudo G, Bonomo A, Di Liberto V, Frinchi M, Fuxe K, Belluardo N. The FGF-2/FGFRs neurotrophic system promotes neurogenesis in the adult brain. J Neural Transm. 2009;116:995-1005.

233. Suh SW, Aoyama K, Alano CC, Anderson CM, Hamby AM, Swanson RA. Zinc inhibits astrocyte glutamate uptake by activation of poly(ADP-ribose) polymerase-1. Mol Med. 2007;13:344-9.

234. Tsang M, Dawid IB. Promotion and attenuation of FGF signaling through the Ras-MAPK pathway. Sci STKE. 2004; 2004:pe17.

235. Tsuji L, Yamashita T, Kubo T, Madura T, Tanaka H, Hosokawa K, et al. FLRT3, a cell surface molecule containing LRR repeats and a FNIII domain, promotes neurite outgrowth. Biochem Biophys Res Commun. 2004;313:1086-91.

236. Grote HE, Hannan AJ. Regulators of adult neurogenesis in the healthy and diseased brain. Clin Exp Pharmacol Physiol. 2007;34:533-45.

237. Yang Z, You Y, Levison SW. Neonatal hypoxic/ischemic brain injury induces production of calretinin-expressing interneurons in the striatum. J Comp Neurol. 2008;511:19-33. 
238. Hoglinger GU, Rizk P, Muriel MP, Duyckaerts C, Oertel WH, Caille I, et al. Dopamine depletion impairs precursor cell proliferation in Parkinson disease. Nat Neurosci. 2004;7:726-35.

239. Cameron HA, McEwen BS, Gould E. Regulation of adult neurogenesis by excitatory input and NMDA receptor activation in the dentate gyrus. J Neurosci. 1995;15:4687-92.

240. Brezun JM, Daszuta A. Depletion in serotonin decreases neurogenesis in the dentate gyrus and the subventricular zone of adult rats. Neuroscience. 1999;89:999-1002.

241. Brezun JM, Daszuta A. Serotonin may stimulate granule cell proliferation in the adult hippocampus, as observed in rats grafted with foetal raphe neurons. Eur J Neurosci. 2000;12:3916.

242. Winner B, Geyer M, Couillard-Despres S, Aigner R, Bogdahn U, Aigner L, et al. Striatal deafferentation increases dopaminergic neurogenesis in the adult olfactory bulb. Exp Neurol. 2006; 197:113-21.

243. Van Kampen JM, Hagg T, Robertson HA. Induction of neurogenesis in the adult rat subventricular zone and neostriatum following dopamine D3 receptor stimulation. Eur J Neurosci. 2004; 19:2377-87.

244. Hiramoto T, Kanda Y, Satoh Y, Takishima K, Watanabe Y. Dopamine D2 receptor stimulation promotes the proliferation of neural progenitor cells in adult mouse hippocampus. Neuroreport. 2007; 18:659-64.

245. Goffin D, Ali AB, Rampersaud N, Harkavyi A, Fuchs C, Whitton PS, et al. Dopamine-dependent tuning of striatal inhibitory synaptogenesis. J Neurosci. 2010;30:2935-50.

246. Luo D, Zhang Q, Wang H, Cui Y, Sun Z, Yang J, et al. Fucoidan protects against dopaminergic neuron death in vivo and in vitro. Eur J Pharmacol. 2009;617:33-40.

247. O'Keeffe GC, Barker RA, Caldwell MA. Dopaminergic modulation of neurogenesis in the subventricular zone of the adult brain. Cell Cycle. 2009;8:2888-94.

248. Reuss B, Unsicker K. Survival and differentiation of dopaminergic mesencephalic neurons are promoted by dopamine-mediated induction of FGF-2 in striatal astroglial cells. Mol Cell Neurosci. 2000;16:781-92.

249. Ohta K, Kuno S, Inoue S, Ikeda E, Fujinami A, Ohta M. The effect of dopamine agonists: the expression of GDNF, NGF, and BDNF in cultured mouse astrocytes. J Neurol Sci. 2010;291:12-6.

250. Ohta M, Mizuta I, Ohta K, Nishimura M, Mizuta E, Hayashi K, et al. Apomorphine up-regulates NGF and GDNF synthesis in cultured mouse astrocytes. Biochem Biophys Res Commun. 2000;272:18-22.

251. Guo H, Tang Z, Yu Y, Xu L, Jin G, Zhou J. Apomorphine induces trophic factors that support fetal rat mesencephalic dopaminergic neurons in cultures. Eur J Neurosci. 2002;16:1861-70.

252. Li A, Guo H, Luo X, Sheng J, Yang S, Yin Y, et al. Apomorphine-induced activation of dopamine receptors modulates FGF-2 expression in astrocytic cultures and promotes survival of dopaminergic neurons. FASEB J. 2006;20:1263-5.

253. Konrad K, Eickhoff SB. Is the ADHD brain wired differently? A review on structural and functional connectivity in attention deficit hyperactivity disorder. Hum Brain Mapp. 2010;31:904-16.

254. Herrera-Marschitz M, Arbuthnott G, Ungerstedt U. The rotational model and microdialysis: Significance for dopamine signalling, clinical studies, and beyond. Prog Neurobiol. 2010;90:176-89.

255. Nijboer CH, Heijnen CJ, Groenendaal F, May MJ, van Bel F, Kavelaars A. Strong neuroprotection by inhibition of NF-kappaB after neonatal hypoxia-ischemia involves apoptotic mechanisms but is independent of cytokines. Stroke. 2008;39:2129-37.

256. Fan X, van Bel F. Pharmacological neuroprotection after perinatal asphyxia. J Matern Fetal Neonatal Med. 2010;23 Suppl 3:17-9.
257. Roka A, Azzopardi D. Therapeutic hypothermia for neonatal hypoxic ischaemic encephalopathy. Early Hum Dev. 2010;86:361-7.

258. Kelen D, Robertson NJ. Experimental treatments for hypoxic ischaemic encephalopathy. Early Hum Dev. 2010;86:369-77.

259. Herrera-Marschitz M, Loidl CF, Andersson K, Ungerstedt U. Prevention of mortality induced by perinatal asphyxia: hypothermia or glutamate antagonism? Amino Acids. 1993;5:413-9.

260. Thoresen M, Bagenholm R, Loberg EM, Apricena F, Kjellmer I. Posthypoxic cooling of neonatal rats provides protection against brain injury. Arch Dis Child Fetal Neonatal Ed. 1996;74:F3-9.

261. Engidawork E, Loidl F, Chen Y, Kohlhauser C, Stoeckler S, Dell'Anna E, et al. Comparison between hypothermia and glutamate antagonism treatments on the immediate outcome of perinatal asphyxia. Exp Brain Res. 2001;138:375-83.

262. Gunn AJ, Gunn TR. The 'pharmacology' of neuronal rescue with cerebral hypothermia. Early Hum Dev. 1998;53:19-35.

263. Eicher DJ, Wagner CL, Katikaneni LP, Hulsey TC, Bass WT, Kaufman DA, et al. Moderate hypothermia in neonatal encephalopathy: safety outcomes. Pediatr Neurol. 2005;32:18-24.

264. Gunn AJ, Bennet L. Is temperature important in delivery room resuscitation? Semin Neonatol. 2001;6:241-9.

265. Drury PP, Bennet L, Gunn AJ. Mechanisms of hypothermic neuroprotection. Semin Fetal Neonatal Med. 2010;15:287-92.

266. Gluckman P, Klempt N, Guan J, Mallard C, Sirimanne E, Dragunow $\mathrm{M}$, et al. A role for IGF-1 in the rescue of CNS neurons following hypoxic-ischemic injury. Biochem Biophys Res Commun. 1992;182:593-9.

267. Shankaran S, Laptook AR, Ehrenkranz RA, Tyson JE, McDonald SA, Donovan EF, et al. Whole-body hypothermia for neonates with hypoxic-ischemic encephalopathy. N Engl J Med. 2005;353:1574 84 .

268. Pfister RH, Soll RF. Hypothermia for the treatment of infants with hypoxic-ischemic encephalopathy. J Perinatol. 2010;30 (Suppl):S82-7.

269. Herrera-Marschitz M, Loidl CF, You ZB, Andersson K, Silveira R, O'Connor WT, et al. Neurocircuitry of the basal ganglia studied by monitoring neurotransmitter release. Effects of intracerebral and perinatal asphyctic lesions. Mol Neurobiol. 1994;9:171-82.

270. Meyn Jr DF, Ness J, Ambalavanan N, Carlo WA. Prophylactic phenobarbital and whole-body cooling for neonatal hypoxicischemic encephalopathy. J Pediatr. 2010;157:334-6.

271. Barks JD, Liu YQ, Shangguan Y, Silverstein FS. Phenobarbital augments hypothermic neuroprotection. Pediatr Res. 2010;67:532-7.

272. Filippi L, Poggi C, la Marca G, Furlanetto S, Fiorini P, Cavallaro $\mathrm{G}$, et al. Oral topiramate in neonates with hypoxic ischemic encephalopathy treated with hypothermia: a safety study. J Pediatr. 2010;157:361-6.

273. Liu C, Lin N, Wu B, Qiu Y. Neuroprotective effect of memantine combined with topiramate in hypoxic-ischemic brain injury. Brain Res. 2009;1282:173-82.

274. Cilio MR, Ferriero DM. Synergistic neuroprotective therapies with hypothermia. Semin Fetal Neonatal Med. 2010;15:293-8.

275. Chakkarapani E, Dingley J, Liu X, Hoque N, Aquilina K, Porter $\mathrm{H}$, et al. Xenon enhances hypothermic neuroprotection in asphyxiated newborn pigs. Ann Neurol. 2010;68:330-41.

276. Cetinkaya M, Alkan T, Ozyener F, Kafa IM, Kurt MA, Koksal N. Possible neuroprotective effects of magnesium sulfate and melatonin as both pre- and post-treatment in a neonatal hypoxicischemic rat model. Neonatology. 2010;99:302-10.

277. Dzhala VI, Kuchibhotla KV, Glykys JC, Kahle KT, Swiercz WB, Feng G, et al. Progressive NKCC1-dependent neuronal chloride accumulation during neonatal seizures. J Neurosci. 2010;30: $11745-61$. 
278. Jagtap P, Szabo C. Poly(ADP-ribose) polymerase and the therapeutic effects of its inhibitors. Nat Rev Drug Discov. 2005;4:421-40.

279. Trucco C, Oliver FJ, de Murcia G, Menissier-de Murcia J. DNA repair defect in poly(ADP-ribose) polymerase-deficient cell lines. Nucleic Acids Res. 1998;26:2644-9.

280. Schultz N, Lopez E, Saleh-Gohari N, Helleday T. Poly(ADPribose) polymerase (PARP-1) has a controlling role in homologous recombination. Nucleic Acids Res. 2003;31:4959-64.

281. Geraets L, Moonen HJ, Wouters EF, Bast A, Hageman GJ. Caffeine metabolites are inhibitors of the nuclear enzyme poly (ADP-ribose)polymerase-1 at physiological concentrations. Biochem Pharmacol. 2006;72:902-10.

282. Chong ZZ, Maiese K. Enhanced tolerance against early and late apoptotic oxidative stress in mammalian neurons through nicotinamidase and sirtuin mediated pathways. Curr Neurovasc Res. 2008;5:159-70.

283. Maiese K, Chong ZZ, Hou J, Shang YC. The vitamin nicotinamide: translating nutrition into clinical care. Molecules. 2009; $14: 3446-85$.

284. Sauve AA. NAD+ and vitamin B3: from metabolism to therapies. J Pharmacol Exp Ther. 2008;324:883-93.

285. Goffus AM, Anderson GD, Hoane M. Sustained delivery of nicotinamide limits cortical injury and improves functional recovery following traumatic brain injury. Oxid Med Cell Longev. 2010;3:145-52.

286. Yan Q, Briehl M, Crowley CL, Payne CM, Bernstein H, Bernstein $\mathrm{C}$. The NAD+ precursors, nicotinic acid and nicotinamide upregulate glyceraldehyde-3-phosphate dehydrogenase and glucose-6-phosphate dehydrogenase mRNA in Jurkat cells. Biochem Biophys Res Commun. 1999;255:133-6.

287. Wan FJ, Lin HC, Kang BH, Tseng CJ, Tung CS. Damphetamine-induced depletion of energy and dopamine in the rat striatum is attenuated by nicotinamide pretreatment. Brain Res Bull. 1999;50:167-71.

288. Sakakibara Y, Mitha AP, Ogilvy CS, Maynard KI. Post-treatment with nicotinamide (vitamin $\mathrm{B}(3)$ ) reduces the infarct volume following permanent focal cerebral ischemia in female SpragueDawley and Wistar rats. Neurosci Lett. 2000;281:111-4.

289. Ducrocq S, Benjelloun N, Plotkine M, Ben-Ari Y, CharriautMarlangue C. Poly(ADP-ribose) synthase inhibition reduces ischemic injury and inflammation in neonatal rat brain. $\mathrm{J}$ Neurochem. 2000;74:2504-11.

290. Zhang J, Steiner JP. Nitric oxide synthase, immunophilins and poly(ADP-ribose) synthetase: novel targets for the development of neuroprotective drugs. Neurol Res. 1995;17:285-8.

291. Bustamante D, Goiny M, Astrom G, Gross J, Andersson K, Herrera-Marschitz M. Nicotinamide prevents the long-term effects of perinatal asphyxia on basal ganglia monoamine systems in the rat. Exp Brain Res. 2003;148:227-32.

292. Bustamante D, Morales P, Pereyra JT, Goiny M, HerreraMarschitz M. Nicotinamide prevents the effect of perinatal asphyxia on dopamine release evaluated with in vivo microdialysis 3 months after birth. Exp Brain Res. 2007;177:35869.

293. Ferre S, Herrera-Marschitz M, Grabowska-Anden M, Casas M, Ungerstedt U, Anden NE. Postsynaptic dopamine/adenosine interaction: II. Postsynaptic dopamine agonism and adenosine antagonism of methylxanthines in short-term reserpinized mice. Eur J Pharmacol. 1991;192:31-7.

294. Khan M, Sekhon B, Jatana M, Giri S, Gilg AG, Sekhon C, et al. Administration of $\mathrm{N}$-acetylcysteine after focal cerebral ischemia protects brain and reduces inflammation in a rat model of experimental stroke. J Neurosci Res. 2004;76:519-27.

295. Pei Z, Pang SF, Cheung RT. Administration of melatonin after onset of ischemia reduces the volume of cerebral infarction in a rat middle cerebral artery occlusion stroke model. Stroke. 2003;34:770-5.

296. Chaudhari T, McGuire W. Allopurinol for preventing mortality and morbidity in newborn infants with suspected hypoxicischaemic encephalopathy. Cochrane Database Syst Rev. 2008; CD006817.

297. West T, Atzeva M, Holtzman DM. Pomegranate polyphenols and resveratrol protect the neonatal brain against hypoxic-ischemic injury. Dev Neurosci. 2007;29:363-72.

298. Northington FJ, Chavez-Valdez R, Graham EM, Razdan S, Gauda EB, Martin LJ. Necrostatin decreases oxidative damage, inflammation, and injury after neonatal HI. J Cereb Blood Flow Metab. 2011;31:178-89.

299. Zhong J, Zhao L, Du Y, Wei G, Yao WG, Lee WH. Delayed IGF1 treatment reduced long-term hypoxia-ischemia-induced brain damage and improved behavior recovery of immature rats. Neurol Res. 2009;31:483-9.

300. Holtzman DM, Sheldon RA, Jaffe W, Cheng Y, Ferriero DM. Nerve growth factor protects the neonatal brain against hypoxicischemic injury. Ann Neurol. 1996;39:114-22.

301. Han BH, Holtzman DM. BDNF protects the neonatal brain from hypoxic-ischemic injury in vivo via the ERK pathway. J Neurosci. 2000;20:5775-81.

302. Russell JC, Szuflita N, Khatri R, Laterra J, Hossain MA. Transgenic expression of human FGF-1 protects against hypoxic-ischemic injury in perinatal brain by intervening at caspase-XIAP signaling cascades. Neurobiol Dis. 2006;22:67790.

303. Wakabayashi K, Nagai A, Sheikh AM, Shiota Y, Narantuya D, Watanabe T, et al. Transplantation of human mesenchymal stem cells promotes functional improvement and increased expression of neurotrophic factors in a rat focal cerebral ischemia model. J Neurosci Res. 2010;88:1017-25.

304. Titomanlio L, Bouslama M, Verche VL, Dalous J, Kaindl AM, Tsenkina $\mathrm{Y}$, et al. Implanted neurosphere-derived precursors promote recovery after neonatal excitotoxic brain injury. Stem Cells Dev. 2011;20:865-79.

305. Lee JA, Kim BI, Jo CH, Choi CW, Kim EK, Kim HS, et al. Mesenchymal stem-cell transplantation for hypoxic-ischemic brain injury in neonatal rat model. Pediatr Res. 2010;67:42-6.

306. Pimentel-Coelho PM, Mendez-Otero R. Cell therapy for neonatal hypoxic-ischemic encephalopathy. Stem Cells Dev. 2010;19:299-310.

307. van Velthoven CT, Kavelaars A, van Bel F, Heijnen CJ. Nasal administration of stem cells: a promising novel route to treat neonatal ischemic brain damage. Pediatr Res. 2010;68:419-22.

308. van Velthoven CT, Kavelaars A, van Bel F, Heijnen CJ. Mesenchymal stem cell transplantation changes the gene expression profile of the neonatal ischemic brain. Brain Behav Immun. 2011; doi:10.1016/j.bbi.2011.03.021.

309. Yasuhara T, Hara K, Maki M, Mays RW, Deans RJ, Hess DC, et al. Intravenous grafts recapitulate the neurorestoration afforded by intracerebrally delivered multipotent adult progenitor cells in neonatal hypoxic-ischemic rats. J Cereb Blood Flow Metab. 2008;28:1804-10.

310. van Velthoven CT, Kavelaars A, van Bel F, Heijnen CJ. Regeneration of the ischemic brain by engineered stem cells: fuelling endogenous repair processes. Brain Res Rev. 2009;61:113.

311. Qu R, Li Y, Gao Q, Shen L, Zhang J, Liu Z, et al. Neurotrophic and growth factor gene expression profiling of mouse bone marrow stromal cells induced by ischemic brain extracts. Neuropathology. 2007;27:355-63.

312. Leker RR, Lasri V, Chernoguz D. Growth factors improve neurogenesis and outcome after focal cerebral ischemia. J Neural Transm. 2009;116:1397-402. 
313. Skaper SD. Neuronal growth-promoting and inhibitory cues in neuroprotection and neuroregeneration. Ann N Y Acad Sci. 2005; 1053:376-85.

314. Pimentel-Coelho PM, Magalhaes ES, Lopes LM, deAzevedo LC, Santiago MF, Mendez-Otero R. Human cord blood transplantation in a neonatal rat model of hypoxic-ischemic brain damage: functional outcome related to neuroprotection in the striatum. Stem Cells Dev. 2010;19:351-8.

315. Cotten CM, Kurtzberg J, Song H, Goldstein R, Provenzale JM. Cordblood for hypoxic-ischemic encephalopathy; NCT00593242. http://clinicaltrials.gov/ct2/show/ NCT00593242 